EXTERNAL TRANSMITTAL AUTHORIZED

Distributimited to R'ec ipiens tindicated

ORNL

Central Files Number

58-10-5

\title{
PRELIMINARY ESTIMATE OF THE COST
}

OF PRODUCING ENRICHED OXYGEN-18

WATER BY DISTILLATION
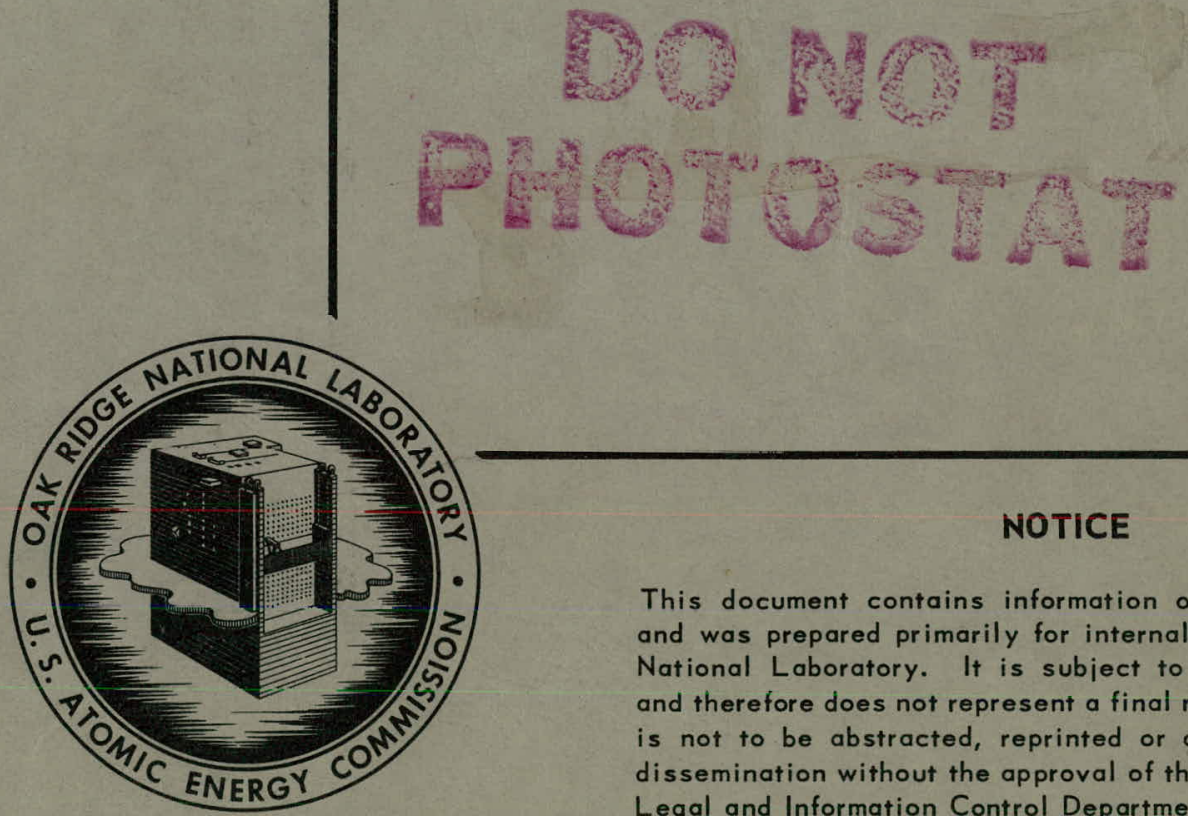

\section{NOTICE}

This document contains information of a preliminary nature and was prepared primarily for internal use at the Oak Ridge National Laboratory. It is subject to revision or correction and therefore does not represent a final report. The information is not to be abstracted, reprinted or otherwise given public dissemination without the approval of the ORNL patent branch, Legal and Information Control Department.

OAK RIDGE NATIONAL LABORATORY

$$
\text { operated by }
$$

\section{UNION CARBIDE CORPORATION}

$$
\text { for the }
$$

\author{
U.S. ATOMIC ENERGY COMMISSION
}




\section{DISCLAIMER}

This report was prepared as an account of work sponsored by an agency of the United States Government. Neither the United States Government nor any agency Thereof, nor any of their employees, makes any warranty, express or implied, or assumes any legal liability or responsibility for the accuracy, completeness, or usefulness of any information, apparatus, product, or process disclosed, or represents that its use would not infringe privately owned rights. Reference herein to any specific commercial product, process, or service by trade name, trademark, manufacturer, or otherwise does not necessarily constitute or imply its endorsement, recommendation, or favoring by the United States Government or any agency thereof. The views and opinions of authors expressed herein do not necessarily state or reflect those of the United States Government or any agency thereof. 


\section{DISCLAIMER}

Portions of this document may be illegible in electronic image products. Images are produced from the best available original document. 


$$
\text { CF-58-10-5 }
$$

Distribution Iimited to Recipients Indicated

External Transmittal Authorized

CF No. $-58-10-5$

Copy No. 5

\title{
PRELIMINARY ESTIMATE OF THE COST OF PRODUCING ENRICHED OXYGEN-18. WATER BY DISTILLATION
}

\author{
J. S。 Drury and B. B...Klima* \\ Chemistry Division
}

Date Issued: OCT 101958
OAK RIDGE NATIONAL LABORATORY
Oak Ridge, Tennessee
Operated by
UNION CARBIDE CORPORATION
for the

U. S A tomic Energy Commission

*Chemical Technology Division

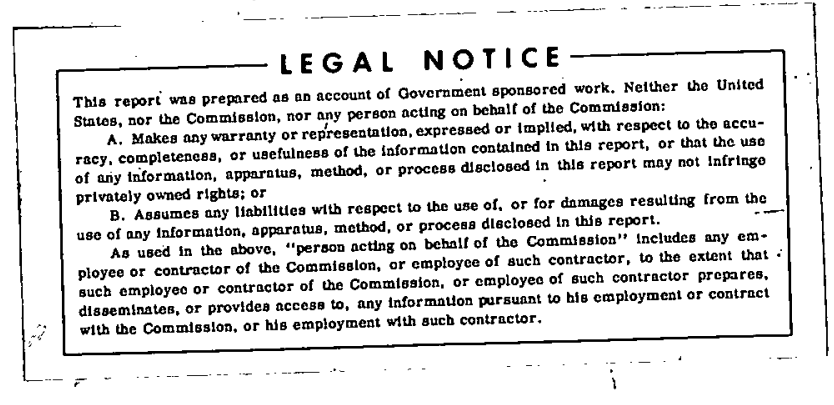


TABLE OF CONTENTS

Page

ABSTRACT . . . . . . . . . . . . . . . . 2

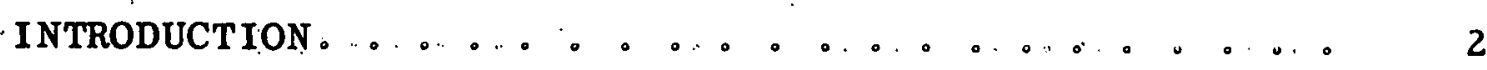

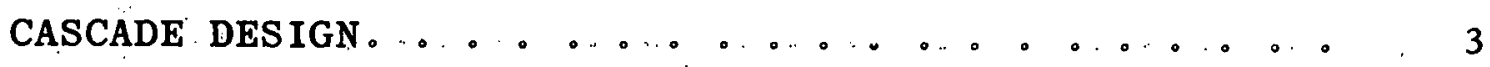

COST ESTIMATING PROCEDURES: ............. 12

SUMMARY OF ESTIMATED COSTS ... . . . . . . . . . ... 13

APPENDIX A D DESIGN CRITERIA . . . . . . . . . . . . 16

APPENDIX B。 COST ESTIMATING CRITERIA .......... 22

APPENDIX C. FLOW DIAGRAMS AND EQUIPMENT LISTS 。 . 27

APPENDIX D . TABULATED COSTS .. $\ldots \ldots \ldots \ldots$

$\begin{array}{lll}\text { APPENDIX: E。 } & \text { VARIATION OF CASCADE COSTS WITH } \\ & \text { PRODUCT PUR ITY AND PRODUCTION RATE. . } & 46\end{array}$

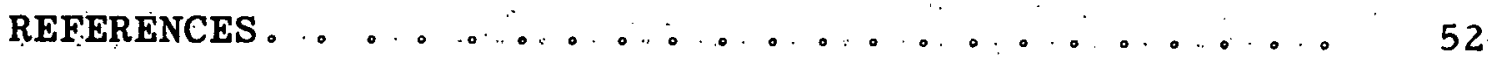




\title{
PRELIMINARY ESTIMATE OF' THE COST OF PRODUCING ENR ICHED OXYGEN-18 WATER BY DISTILLATION
}

\begin{abstract}
An order of magnitude estimate was made to determine the cost of producing oxygen-18 enriched water by the equilibrium distillation of water. Three isotopic purities and two production rates were considered. Costs varied from $\$ 26$ per gram for 3\% 'oxygen-18 enriched water ṕroduced at a rate of 100 grams per day to $\$ 225$ per gram for $99 \%$ oxygen-18 water produced at a rate of one gram per day.
\end{abstract}

\section{Introduction}

For many years oxygen-18 enriched water has been produced in this country as an incidental by-product of the heavy water industry. The oxygen-18 content of this material has varied from slightly enriched to eight times normal abundance, depending on the particular enrichment process employed. Enrichment of large quantities of oxygen-18 to concentrations greater than $1=2 \%$ has not been undertaken in the United states. It is the purpose of this report to estimate the order of magnitude cost of producing enriched oxygen-18 water in this country. 
The equilibrium distillation of water was the enrichment process chosen for consideration in this report. This method has several advantages over existing competitive processes. It utilizes'a cheap, non-corrosive feed material, a relatively inexpensive refluxing mechanism, and a simple operational procedure. The major disadvantages of the method are its low separation factor and the associated long isotopic equilibrium time.. Despite these shortcomings, the distillation method is considered to be the most attractive process for the production of multigram quantities of enriched oxygen-18 water at the present time。

\section{Cascade Design}

The enrichment of oxygen-18 in three isotopic purities and at two production rates was considered. The product purities chosen were $3 \%, 40 \%$, and $99 \%$ oxygen-18. The production rates were 1 and 100 grams per day for the higher purities. For the $3 \%$ case, the smaller production rate was doubled.

Three basic cascades were designed for the lower production rate, one each for the low, intermediate, and high purity product. The cascade designed for product of intermediate purity was sçaled up to allow a hundredfold increase in its production rate. Costs for the low and high purity cascades at the higher production rate were extrapolated from cost 
data obtained from the other four cascades.

Oxygen-17 which has a normal abundance of $0.04 \%$ was neglected in the foregoing calculations. This simplification introduces no significant error into the calculation of the cascades for production of low and intermediate purity oxygen-18. However, in the case of the cascade producing high purity oxygen-18, an allowance must be made. The purity stated for the product of the latter cascade includes both oxygen-17 and oxygen-18. It is estimated that the product would contain $1-2 \%$ oxygen-17 with a corresponding decrease in the oxygen-18 content. Oxygen-17 of higher purity, perhaps up to $5 \%$ oxygen -17 , would be available at an intermediate point in the cascade if desired. However, withdrawal of oxygen-17 at this point would reduce the oxygen-18 yield of the cascade。

Each cascade was designed as a series of columns of decreasing diameter in order to minimize holdup, equilibrium time and capital investment. The required taper was approximated first from plots of $V_{m i n} / D$, minimum reflux ratio, vs. $\mathrm{X}_{\mathrm{n}}$, mole fraction of product in downflow at a given stage 。 Several variations of these preliminary configurations then were calculated to refine the design with respect to the length and width of each section. The cascades which evolved are thought to be reasonable, though not necessarily optimum, designs upon which cost estimates might be made. The criteria 
used in designing the cascades are given in Appendix " $A$ ".

\section{Cascade 1}

The first cascade was designed to produce $99 \%$ oxygen-18 water at the rate of one gram per day. This cascade (Fig. 1) consists of three packed distillation columns with associated reboilers, condensers, pumps, storage vëssels, vacuum system, and coolant towers. Feed is introduced as steam into the first column at a point about one-third column length from the top. The first column thus serves as both a stripper and an enricher. One half of the contained oxygen-18 is removed from the feed stream. Intercolumn transfer is accomplished by means of partial and total condensers, following the technique ${ }^{l}$ used by Dostrovsky, et al, in the construction of the: Weizmann Institute cascade. In this transfer method, the entire interstage flow from a particular column is condensed in a total condenser and the liquid is passed down the cascade to the reboiler of the next largest column. An equivalent amount of steam from the latter column is condensed in a partial condenser by the addition of precisely enough cooling water, and this condensate is fed by gravity into the former column. This technique eliminates the need for moving parts in the transfer process and, hence, is less prone to fail during the long periods of continuous operation required to enrich the heavy isotopes of oxygen. 
Cascade 1

See Table 1 for Key
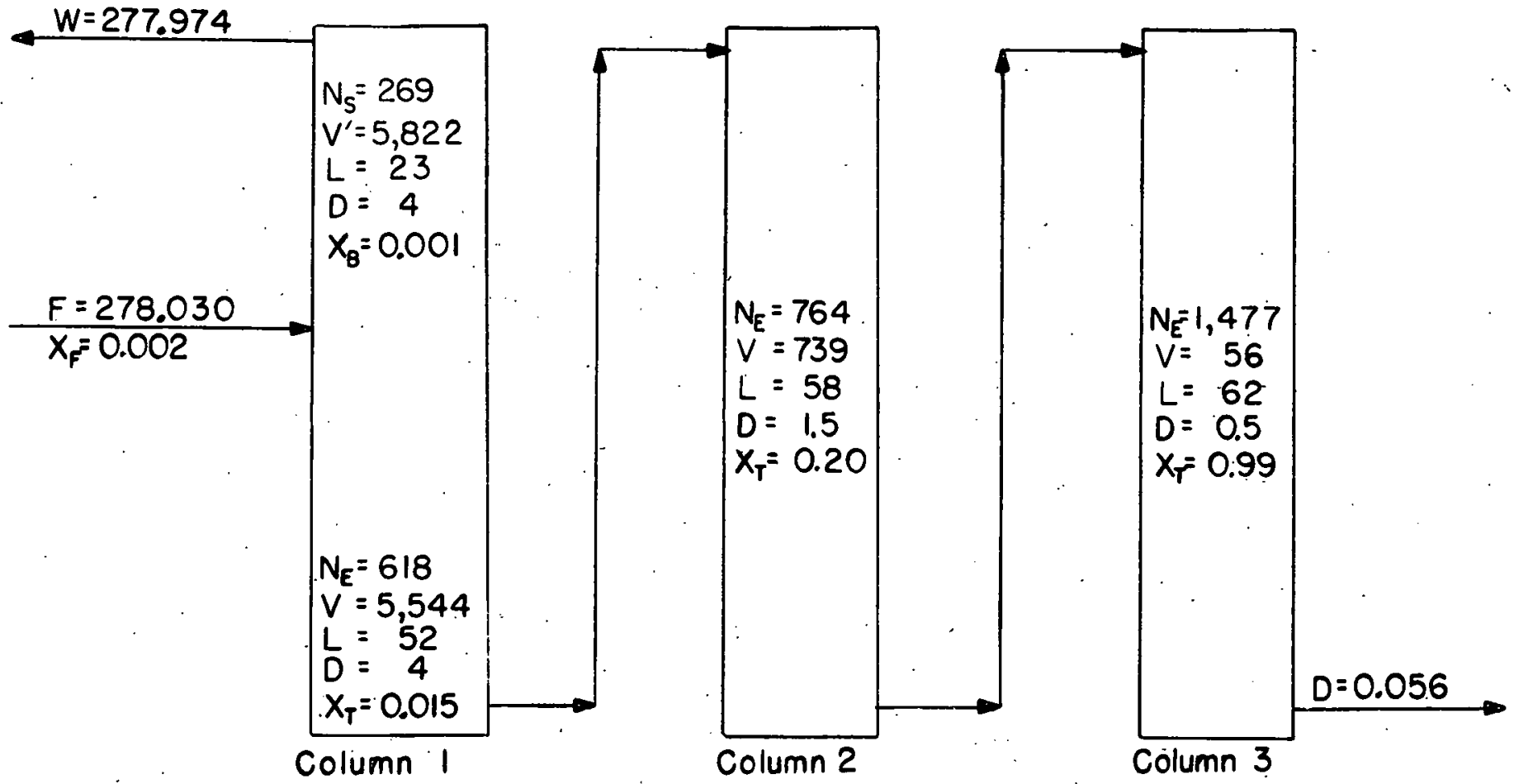
Cascade 2

The second cascade (Fig. 2) was designed to produce $40 \%$ oxygen-18 water at the rate of one gram per day. Except for 'size and product purity, this cascade is identical to Cascade 1.

\section{Cascade 3}

The third cascade (Fig. 3) was designed to produce water containing $3 \%$ oxygen-18. This cascade consists of two distillation columns and related equipment. Initially, this plant was sized for one gram of product per day, but this production rate led to such a small second stage distillation unit that the production rate was doubled to permit use of standard size components.

\section{Cascade 5}

This cascade (Fig. 4) was designed to produce 100 grams per day of water containing $40 \%$ oxygen-18. It is a direct scale-up of Cascade 2. The higher production rate of this plant requires the use of relatively large diameter distillation columns. The longer stage heights associated with these large units lead to extremely long distillation columns. In practice it would be desirable to use a series of shorter columns to minimize the pressure drop across each distillation unit, but, for purposes of this preliminary estimate, a cascade consisting of one stripping and three enriching columns was chosen. 


\section{Cascade 2}

See Table 1 for Key

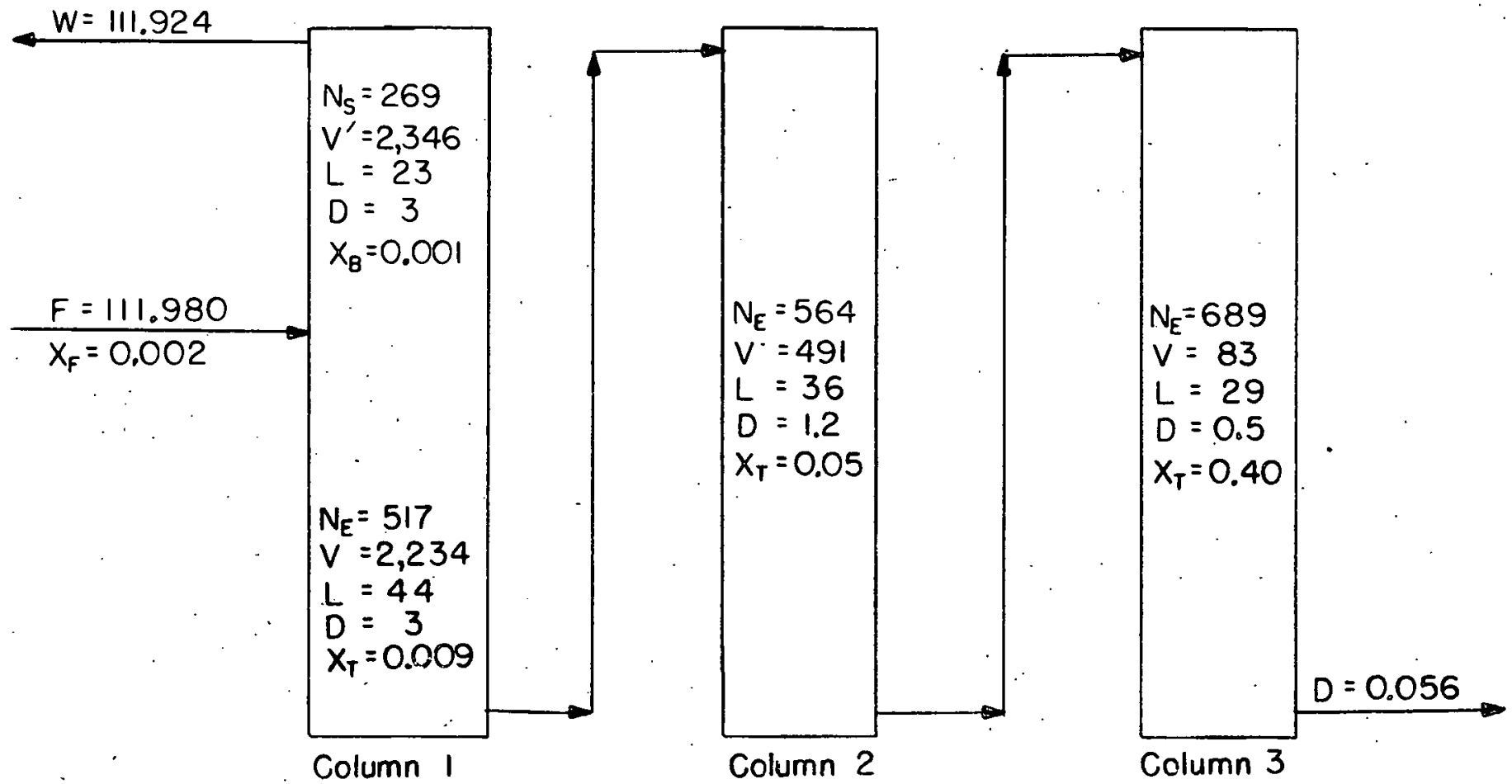

Figure 2. Schematic Diagram of Cascade to Produce One Gram per. Day of Water Enriched to $40 \%$ Oxygen-18 


\section{Cascade 3}

See Table 1. for Key

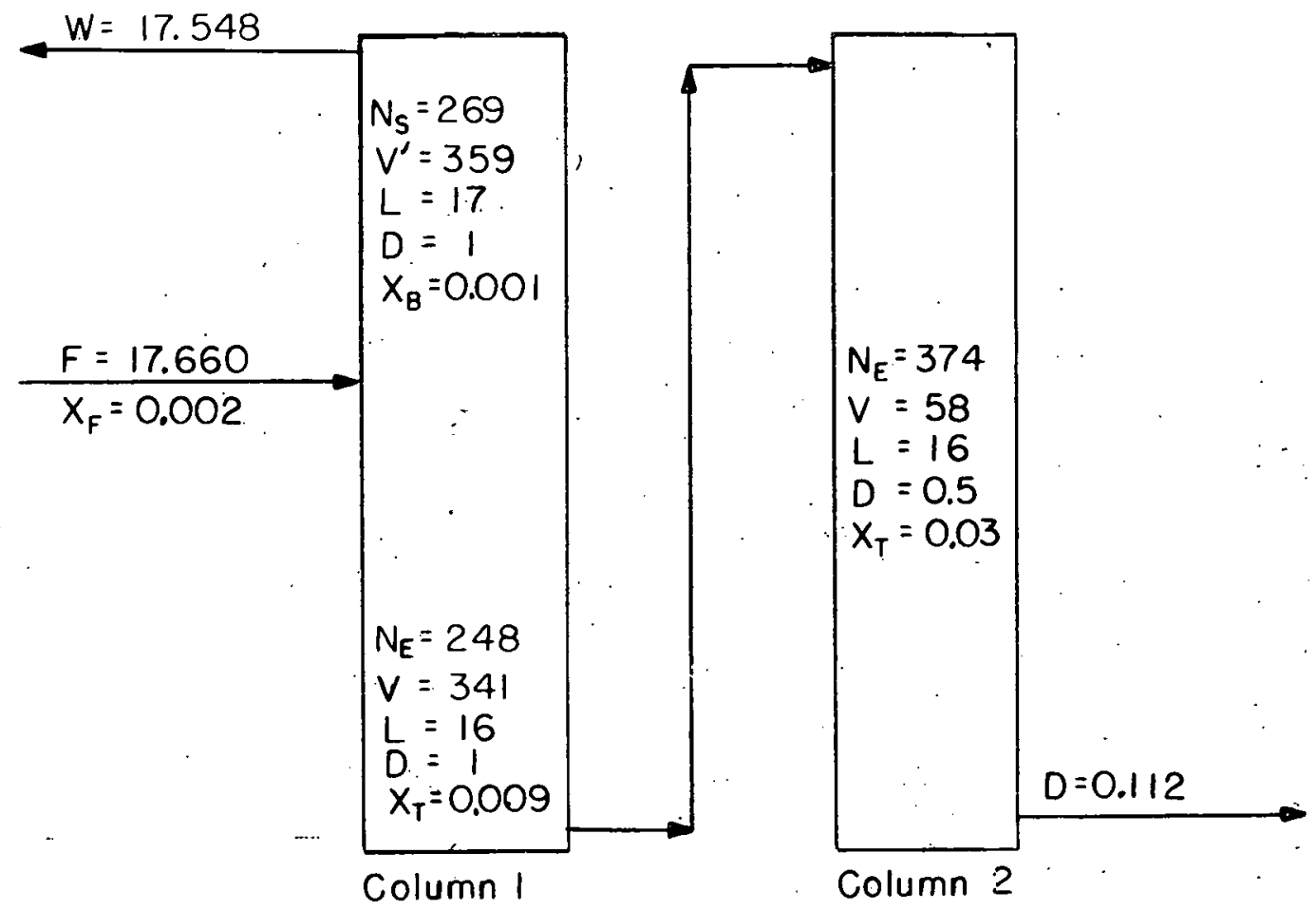

Figure 3.-Schematic:Diagram of Cascade to Produce

Two Grams per Day of Water Enriched to 3\% Oxygen-18 


\section{Cascade 5}

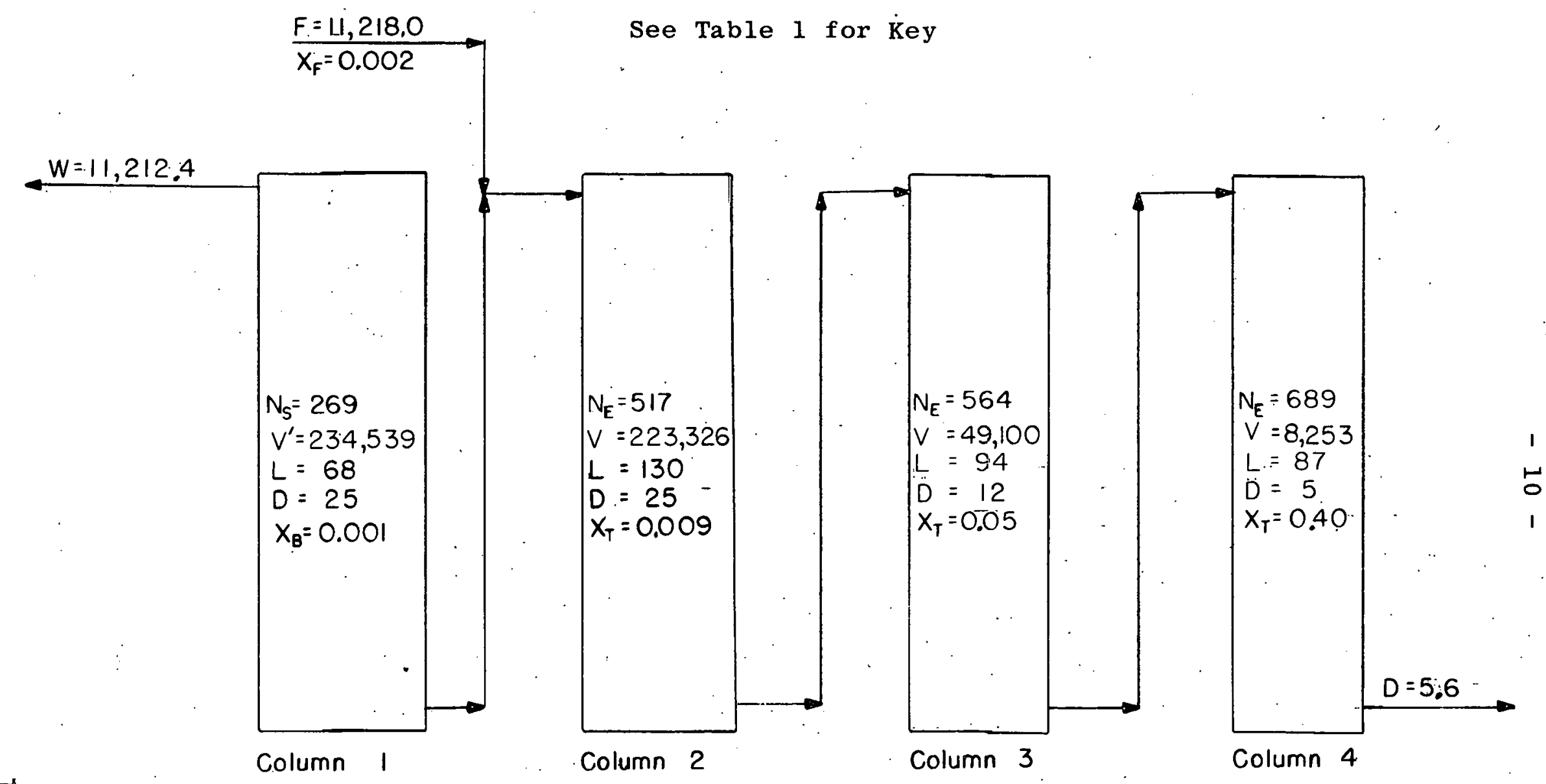

lass

is

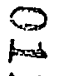

Figure 4. Schematic Diagram of Cascade to Produce One Hundred Grams per. Day of Water Enriched to $40 \%$ Oxygen-18 


\section{Table 1}

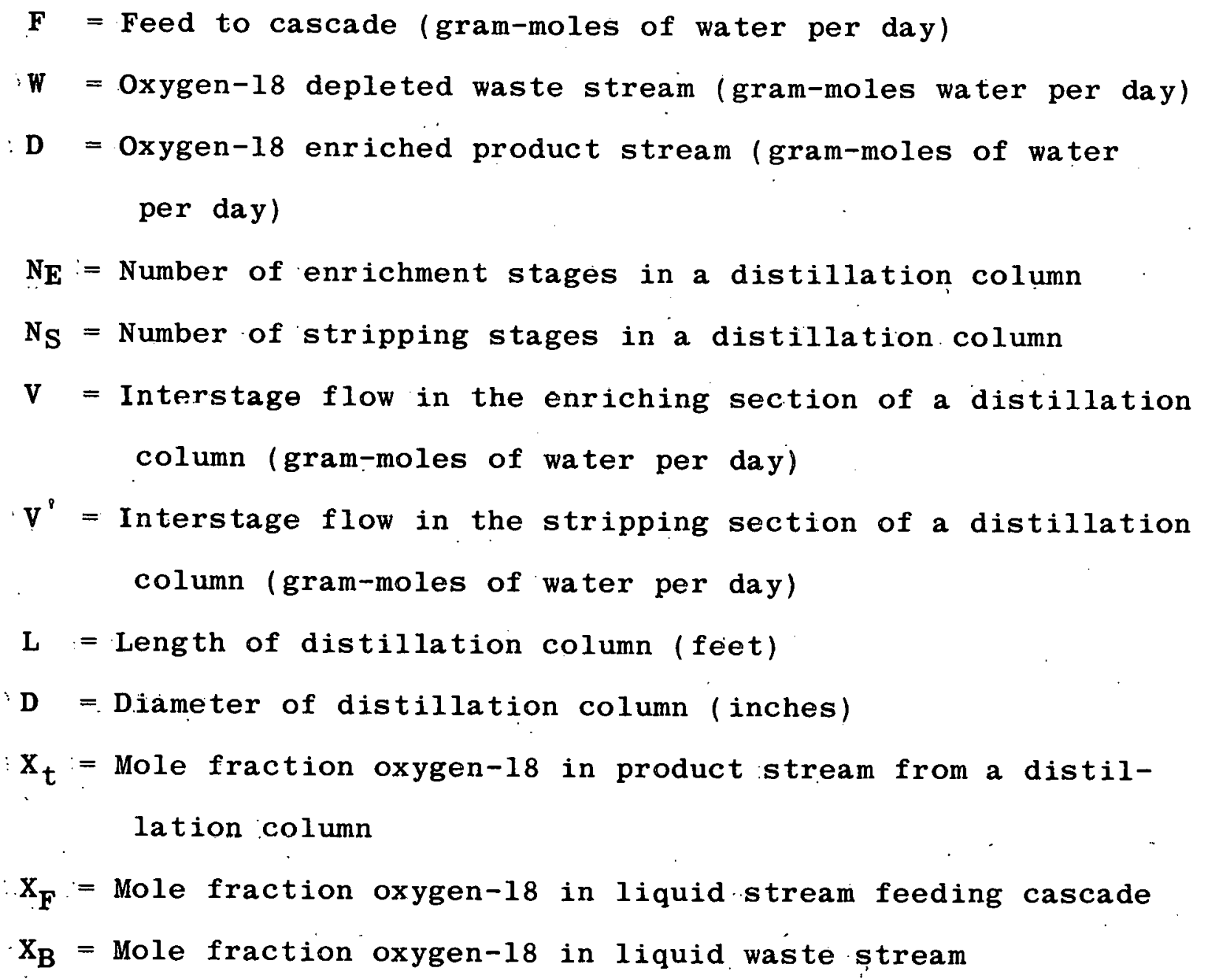




\section{Cascades 4 and 6}

These cascades were not considered in detail. The costs given for these plants were obtained by extrapolating plots of Cost vs. Product Purity for cascades $1,2,3$, and 5 .

\section{Cost Estimating Procedures}

The cost of oxygen-18 enriched water from each cascade was determined by itemizing, sizing and pricing the major pieces of equipment required by the flow sheet of each cascade. The sum of these costs was taken as the total cost of the installed process equipment. These costs then were factored $^{2}$ to obtain the total annual fixed and variable costs for each cascade. An amortization period of $6-2 / 3$ years was assumed in calculating depreciation. Because of the preliminary nature of this estimate, no AEC overhead charges were included. From the production rate and total annual costs of each cascade, the cost per gram of oxygen-18 enriched water was determined. Details of the cost estimates are shown in the appendices. 


\section{Summary of Estimated Costs}

The cost per gram of $99 \%$ oxygen-18 enriched water produced at a rate of one gram per day was estimated to be $\$ 225$. This corresponds to a total annual operating cost slightly greater than $\$ 82,000$. The total plant investment required for such a facility was calculated to be about $\$ 140,000$. Production of $9.9 \%$ oxygen-18 enriched water at a rate of 100 grams per day would reduce the cost of product to $\$ 64$ per gram. However, a total plant investment of approximately $\$ 9,800,000$ and an annual operating cost of about $\$ 2,400,000$ would be required.

Forty per cent oxygen-18 enriched water was estimated to cost about $\$ 186$ per gram when produced at the rate of one gram per day, and about $\$ 52$ when produced at a rate of one hundred grams per day. A total plant investment of some $\$ 86,000$ would be needed for the smaller plant and about $6.127,053$ $\$ 9,800,000-$ for the larger facility. The total annual operating cost for these plants was calculated to be approximately $\$ 68,000$ and $\$ 1,900,000$ 。

Three per cent oxygen-18 enriched water was estimated to cost $\$ 70$ per gram when produced at a rate of 2 grams. per day, and $\$ 26$ per gram when produced at the rate of 100 grams per day. The total investments in these plants amounted to approximately $\$ 37,000$ and $\$ 1,750,00$. Total annual operating expenses were calculated to be about $\$ 51,000$ and $\$ 950,000$. 
Additional cost data are summarized in Table 2 . The costs presented here should be considered minimum costs, obtainable under favorable conditions, since the contingency factors contained in the estimates are modest for isotope separation processes. Several simplifications employed in the estimate, such as the use of a few long columns instead of several short ones, etc, also favor understating the cost of the final product. 
$\underline{\text { Table } 2}$

Summary of Estimated Costs for Producing

\section{Water Enriched in $0^{18}$}

Cascade No 。

Product Purity, \% $0^{18}$

Production Rate, Gms Water per: Day

Total Plant Investment, $\$$

Annual Fixed Cost, $\$$

Annual Variable Cost, $\$$

Total Annual Operating Cost, $\$$

Cost per Gram of $0^{18}$ Enriched $p \rightarrow$

Water, \$

\begin{tabular}{|c|c|c|c|c|c|}
\hline 1 & 2 & 3 & 4 & 5 & 6 \\
\hline 99 & 40 & 3 & . 99 & 40 & 3 \\
\hline 1 & 1 & 2 & 100 & 100 & 100 \\
\hline 139,198 & 85,747 & 36,742 & $9,800,000$ & $6,127,053$ & $1,750,000$ \\
\hline 28,238 & 17,394 & 7,327 & $1,676,000$ & $1,293,933$ & 350,000 \\
\hline 54,008 & 50,564 & 44,052 & 660,000 & 614,771 & 600,000 \\
\hline 82,246 & 67,958 & 51,379 & $2,336,000$ & $1,908,704$ & 950,000 \\
\hline
\end{tabular}

225

186

70

64

52

26 


\section{Appendix "A" - Design Criteria}

The following data, assumptions, and conditions were used in the design of the various cascades described in this report. Product purity:

Three product purities were considered: $3 \%, 40 \%$, and $99 \%$ oxygen -18 .

The presence of oxygen-17 in the feed was ignored.

production rates: (1) 1 gram per day of $99 \%$ oxygen-18 water.

(2) 1 gram per day of $40 \%$ oxygen-18 water.

(3) 2 grams per day of $3 \%$ oxygen-18 water.

(4) 100 grams per day of $40 \%$ oxygen-18 water.

By extrapolating the costs estimated for the above cascades, cost estimates were made for the following cases:

(5) 100 grams per day of $99 \%$ oxygen-18 water.

(6) 100 grams per day of $3 \%$ oxygen-18 water.

Separation factor:

The separation factor varies continuously in a distillation column belcause of the pressure drop across the column. An average value of 1.006 for oxygen-16 - oxygen-18 sepa- 
ration was assumed in this report.

Operating pressure:

Reflux ratio:

Distillation columns:

Column packing:
An average distillation column pressure of $265 \mathrm{~mm} \mathrm{Hg}$ was assumed.

The reflux ratio used in these calculations was 1.2 times the calculated minimum reflux ratio.

The distillation columns were assumed to be constructed of copper pipe insulated for outdoor service.

"Heli-Pak", a metal packing manufactured by Podbielniak, Inc., Chicago, 11, Ilinois, was used in this estimate. The size of the packing varied with the diameter of the distillation columns as follows:

Column

Diameter Type

(inches) No.

$0.5-0.75 \quad 3012 \quad 0.035 \times 0.070 \times 0.070$

$1-4 \quad 30130.050 \times 0.100 \times 0.100$

larger $\quad 3008 \quad 0.092 \times 0.175 \times 0.175$

"Octa-Pak", another packing manufactured by the same company, was considered for use in the larger columns. However, because of longer stage lengths, no economic advantage accrued 
through its use and, for convenience, all columns were assumed to be filled with stainless steel "Heli-Pak"。

HETP : Varying height equivalents of a theoretical plate and holdups were assumed, depending on column diameter, packing size and flow rate:

Column Diameter (inches)

0.5
0.75
1.0
1.5
$2.0-4.0$
$5.0-6: 0$
$10-12$
25

\begin{tabular}{l}
$\begin{array}{c}\text { HETP } \\
\text { (inches) }\end{array}$ \\
\hline 0.5 \\
0.65 \\
0.75 \\
0.90 \\
1.00 \\
1.50 \\
2.00 \\
3.00
\end{tabular}

These estimates are assumed for column loadings of $10 \%$ to $15 \%$ of flooding and are optimistic, especially for the larger columns. Higher loadings reduce the required size of the distillation columns at the expense of stage length, and increase the over-all cost of the installation.

Waste stream: The waste stream was stripped of onehalf of the oxygen-18 initially contained in the feed. 
Holdup:

In the case of the smaller columns, holdup was taken from data supplied by the manufacturer of the packing. These data were extrapolated roughly to obtain estimates of holdup for the larger columns. Column

Diameter (inches)

Holdup
$(\mathrm{ml} / \mathrm{ft}$ of packed column)

0.5
0.75
1.0
1.5
2.0
3.0
4.0
5.0
12.0
25.0
8.6 16 (est.) 28.3 40 . (est.) 60.6 100 (est.)

After the required flow rates were established and the cascade equipment was sized, upper and lower limits were placed upon the estimated equilibrium time of each cascade. The cost of operating the plant the minimum time necessary to reach equilibrium was determined and used as the basis of the pre-operational expense.

Cooling water: Experience ${ }^{3}$ with the Weizmann Institute cascade has shown the need to cool heat exchangers with treated water to 
avoid buildup of deposits and fouling of heat exchange surfaces during the long periods of continuous operation required by oxygen-18 enrichment plants. The use of treated water is assumed in this cost estimate. For economy, this treated water was assumed to be cycled through a cooling tower and reused. A suitable cooling tower was provided for each cascade.

Building:

It was assumed that the various plants would be constructed outdoors. Only office and changehouse space for the operating and supervisory personnel was provided. For the gram-a-day plants, provision was made for one supervisor and four operators. One supervisor and eight operators were allowed in the larger plants.

Scale-up of Cascade $2: \quad$ To obtain estimates of the cost of producing oxygen-18 enriched water at a higher ratè, cascade 2 was resized to permit a hundredfold increase in flow. The same cascade configuration was used as in the one gram per day case. 
$-.21-$

The larger equipment then was priced and factored as before. The direct operating labor required was assumed to be doubled. 


\section{Appendix "B" - Cost.Estimating Criteria}

The various procedures used in determining the reported costs are given below.

Equipment cost:

Building cost:

Total plant investment: The cost of the total physical plant the installed process equipment, pro-

The major pieces of equipment in each cascade first were itemized, then sized, and the installed cost of each item determined. Ten per cent of the installed cost was added in the case of items requiring insulation. Process piping costs were estimated as $60 \%$ of the installed equipment cost. Instru-" mentation was taken as $15 \%$ of the installed equipment cost and the cost of service facilities was assumed to be $50 \%$ of the installed equipment cost. Four hundred and six hundred square feet of space were allowed for office and changehouse facilities for the small and large production rate plants. A cost of $\$ 14.78$ per square foot was assumed for these buildings.

was taken as the sum of the costs of 
cess piping, instrumentation, and the process building. The total plant investment was determined by adding charges to the physical plant cost for engineering, site development, preoperational expenses and contingencies. The cost of engineering was taken as $40 \%$ of the cost of the total physical plant. Site development charges were estimated at $10 \%$ of the total physical plant cost. The pre-operational expenses shown are estimates of the cost of leak testing, equipment shake-down, operator training, and other start-up costs incurred prior to routine operation. This item also includes the minimum estimated cost of operating the plant until isotopic equilibrium is achieved. The contingency factor used was $30 \%$ of the total physical plant $\cos t_{\text {。 }}$

Annual fixed cost:

The fixed cost associated with the construction of these plants was defined as the sum of depreciation charges, investment coṣts and overhead. De- 
preciation was calculated at the standard AEC rate of $15 \%$ per year. Investment costs were calculated as $3 \%$ of the total plant investment。 Overhead was defined as the sum of the costs of maintenance: labor: and supplies plus $60 \%$ of the cost of direct operating labor and supervision. However, for convenience, the overhead on direct labor and supervision was tabulated under Annual Variable Costs.

Annual variable cost: The annual variable cost was defined as the cost of direct operating labor and supervision (including overhead), utilities, maintenance labor and supplies, isotopic and chemical ana1yses, storage and miscellaneous. The working force for the smail (1 gram per day) plants was assumed to consist of 1 operator per shift plus 1 supervisor per day.-The large (100 grams per day) plants were assumed to have 2 operators per shift and 1 supervisor per day. Labor charges of $\$ 3.00$ and $\$ 4.85$ per hour, including overhead, 
were assumed for operators and supervisors, respectively. Utilities, maintenance labor, and storage costs each were taken as $5 \%$ of the cost of the total physical plant. The cost of maintenance supplies was estimated at $0.5 \%$; of the cost of the total physical plant. Analytical costs were based upon a minimum sampling program--one isotopic analysis per distillation column per day at $\$ 10.00$ per sample.

Total annual operating $\cos t:$

Cost per gram of oxygen18 enriched water:

Extrapolated estimates for cascades 4 and 6 :
The total annual variable and fixed costs were added to give the total annual operating cost.

The total annual operating cost was divided by the annual product yield to obtain the cost per gram of product

Cascades 4 and 6 were not studied in detail. Instead, estimates of the reported costs were made by plotting the various costs of cascades 1,2 , 3, and 5 as: a function of product purity. Costs for cascade 3 were 
adjusted to the one gram per day production rate by use of the 0.6 factor. 4 The respective costs for cascades 4 and 6 then were obtained by passing a curve through the data point calculated for cascade 5 and parallel to the curve drawn through the one-gram-per-day points calculated for cascades 1,2 , and 3. This method yields only rough approximations at best, but the resulting precision was deemed sufficient for the purpose of this report. Except for annual variable costs, which were sensitive to production rates and insensitive to product purities, the data obtained by this method were surprisingly consistent. Some adjustments were made in the data for cascade 6 to obtain internal consistency. 


\section{Appendix "C" - Flow :Diagrams and Equipment Lists}

Simplified flow diagrams depicting the major pieces of equipment of each cascade are shown on the following pages. ; For convenience, the cooling system and spare items are not shown on the flow sheets. However, all major items appear in the tabulated equipment 1 ist immediately following each flow sheet. Prices were obtained from the manufacturer or from Chilton ${ }^{2}$ and were corrected to the 1958 cost level. 
Cascade No. 1

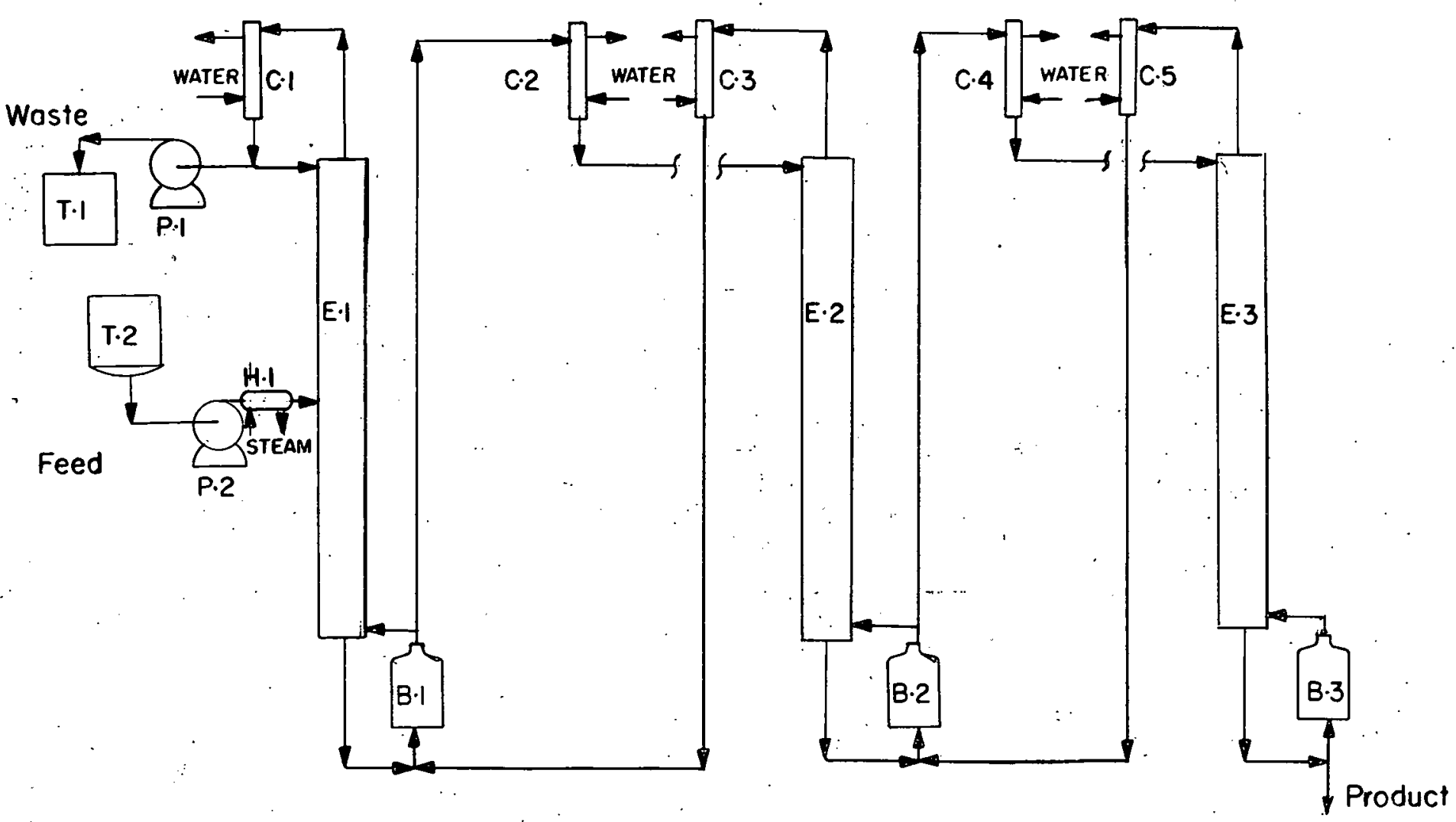

Figure C-1. Simplified Equipment. Diagram of Cascade to Produce 1 Gram per. Day of $99 \%$ Oxygen-18. Water 
Table C-1. Cost of Installed Equipment

Cascade No. 1

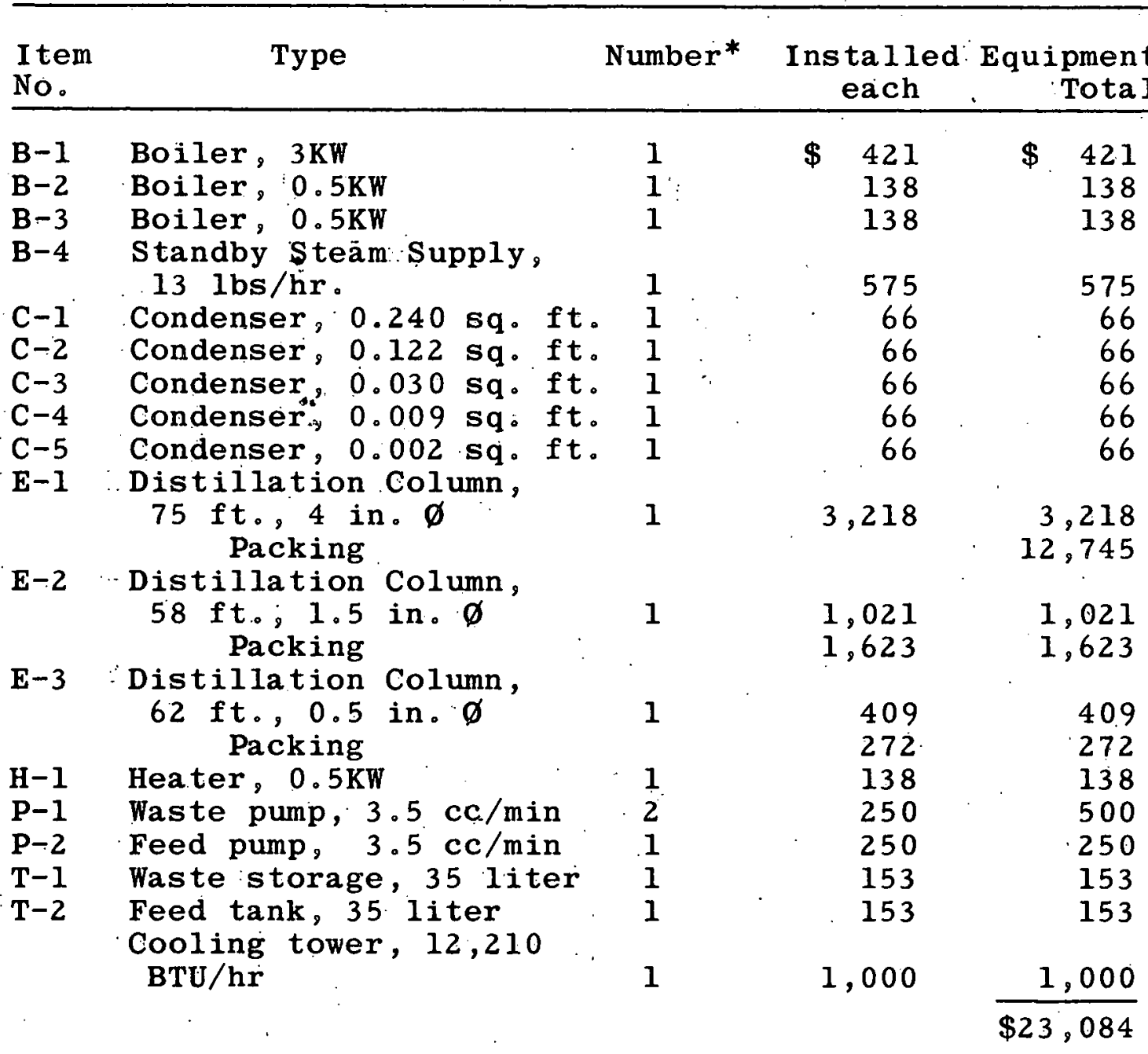

*Includes spares where necessary. 


\section{Cascade No. $* 2$}

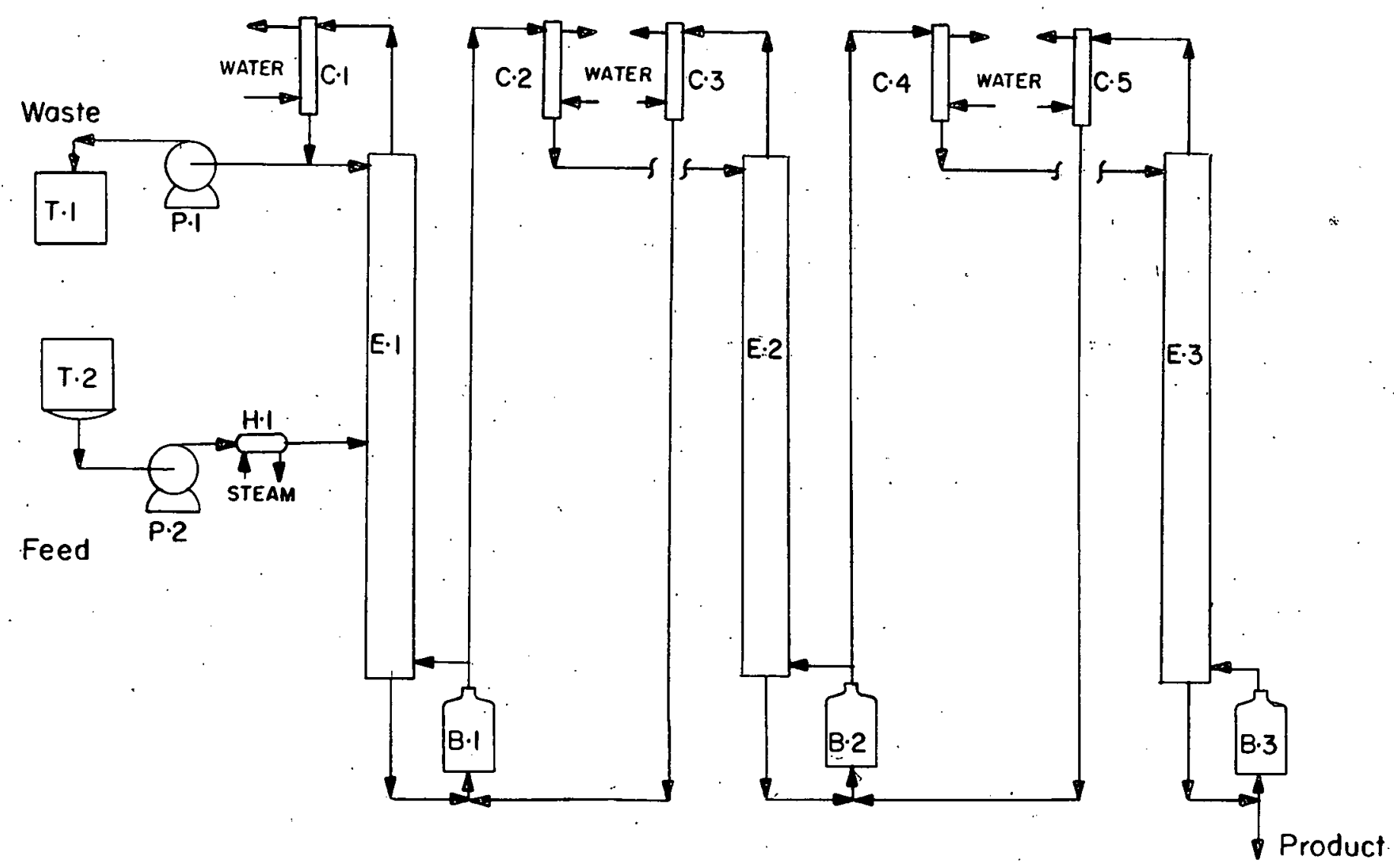


Table C-2。 Cost of Installed Equipment Cascade No. 2

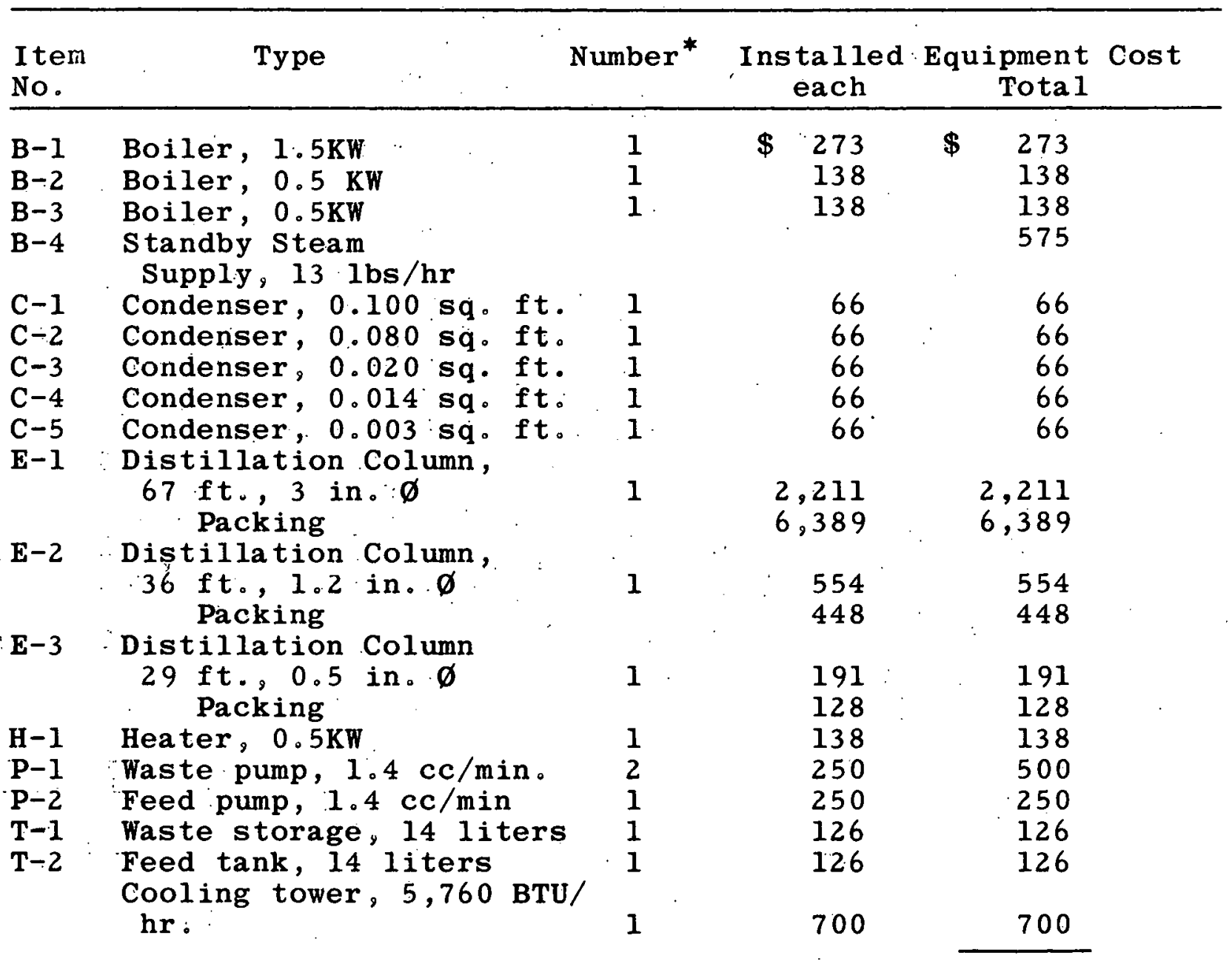

$\$ 13,215$

* Includes spares. where necessary. 
Cascade No. 3

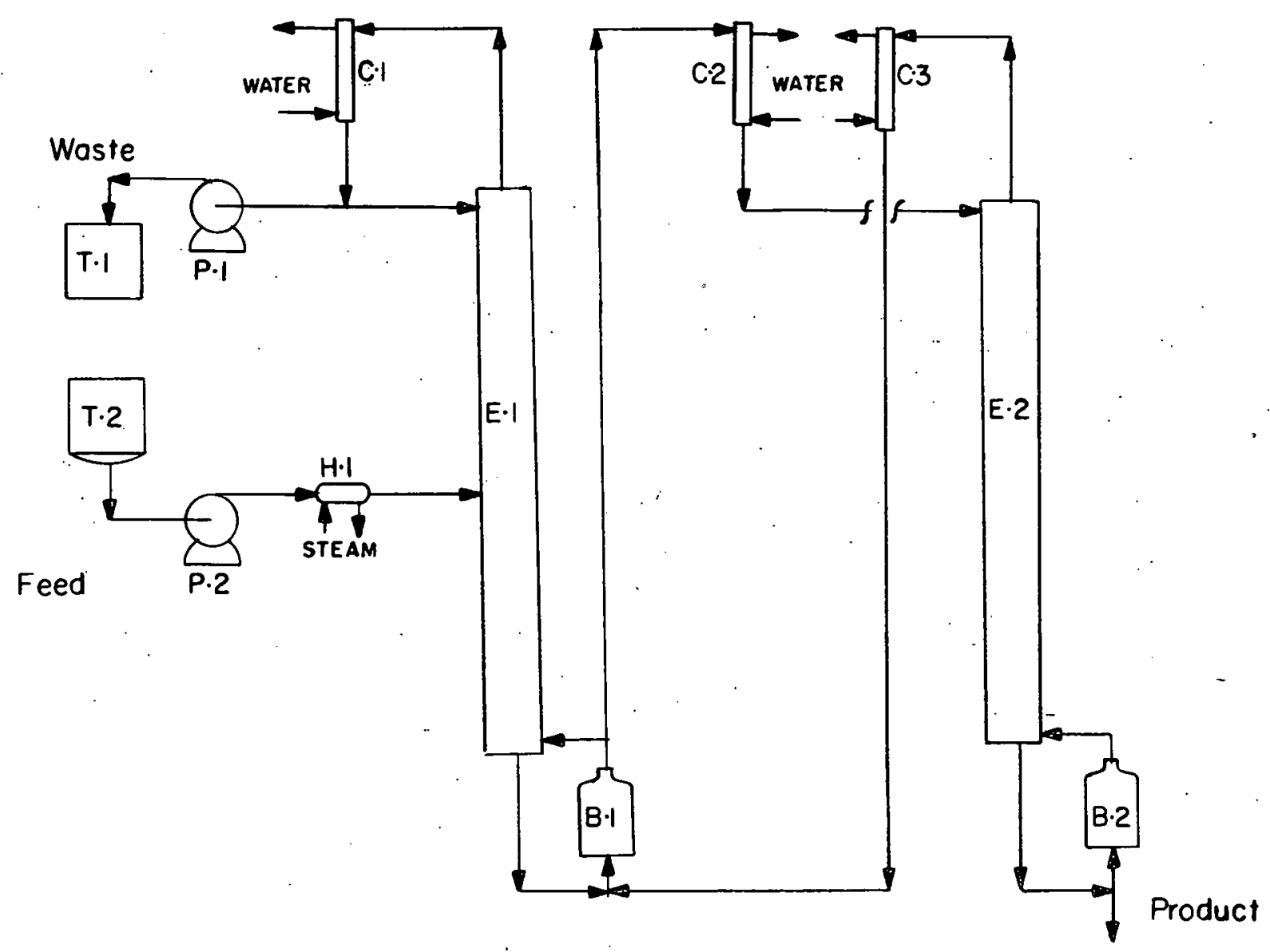

Figure C-3. Simplified Equipment Diagram of Cascade

to Produce 2 Grams per day of 3\% Oxygen-18 Water 
Table C-3. Cost of Installed Equipment

Cascade No. 3

\begin{tabular}{|c|c|c|c|c|c|c|c|}
\hline $\begin{array}{l}\text { Item } \\
\text { No. }\end{array}$ & Type & Number. & \multicolumn{2}{|c|}{$\begin{array}{c}\text { Installed } \\
\text { each }\end{array}$} & \multicolumn{2}{|c|}{$\begin{array}{r}\text { Equipment } \\
\text { Tota } 1\end{array}$} & $\operatorname{Cos} t$ \\
\hline $\begin{array}{l}B-1 \\
B-2 \\
B-3\end{array}$ & $\begin{array}{l}\text { Boiler, } 0.5 \mathrm{KW} \\
\text { Boiler, } 0.5 \mathrm{KW} \\
\text { Standby Steam } \\
\text { Supply, } 13 \mathrm{lbs} / \mathrm{hr}\end{array}$ & $\begin{array}{l}i \\
1\end{array}$ & $\$$ & $\begin{array}{l}138 \\
138\end{array}$ & $\$$ & $\begin{array}{l}138 \\
138 \\
575\end{array}$ & \\
\hline $\begin{array}{l}C-1 \\
C-2 \\
C-3 \\
E-1\end{array}$ & $\begin{array}{l}\text { Condenser, } 0.02 \text { sq. ft. } \\
\text { Condenser, } 0.01 \text { sq. ft. } \\
\text { Condenser, } 0.003 \text { sq. ft. } \\
\text { Distillation Column, }\end{array}$ & 1 & & $\begin{array}{l}66 \\
66 \\
66\end{array}$ & - & $\begin{array}{l}66 \\
66 \\
66\end{array}$ & \\
\hline & $\begin{array}{l}33 \text { ft. } 1 \text { in. } \varnothing \\
\text { Packing }\end{array}$ & 1 & & $\begin{array}{l}399 \\
411\end{array}$ & & $\begin{array}{l}399 \\
411\end{array}$ & \\
\hline$E-2$ & $\begin{array}{c}\text { Distillation Column, } \\
16 \text { fto } 0.5 \text { in. } \emptyset \\
\text { Packing }\end{array}$ & 1 & & $\begin{array}{r}106 \\
71\end{array}$ & . & $\begin{array}{r}106 \\
71\end{array}$ & . \\
\hline $\begin{array}{l}\mathrm{H}-1 \\
\mathrm{P}-1 \\
\mathrm{P}-2 \\
\mathrm{~T}-1 \\
\mathrm{~T}-2\end{array}$ & $\begin{array}{l}\text { Heater, } 0.5 \mathrm{KW} \\
\text { Waste pump, } 13.3 \mathrm{cc} / \mathrm{hr} \\
\text { Feed pump, } 13.3 \mathrm{cc} / \mathrm{hr} \\
\text { Waste storage, } 2 \text { liters } \\
\text { Feed tank, } 2 \text { liters }\end{array}$ & $\begin{array}{l}1 \\
2 \\
1 \\
1 \\
1\end{array}$ & & $\begin{array}{l}138 \\
250 \\
250 \\
108 \\
108\end{array}$ & & $\begin{array}{l}138 \\
500 \\
250 \\
108 \\
108\end{array}$ & . \\
\hline & & & & & &, 140 & \\
\hline
\end{tabular}

*Includes spareś where necessary。 
Cascade No. 5

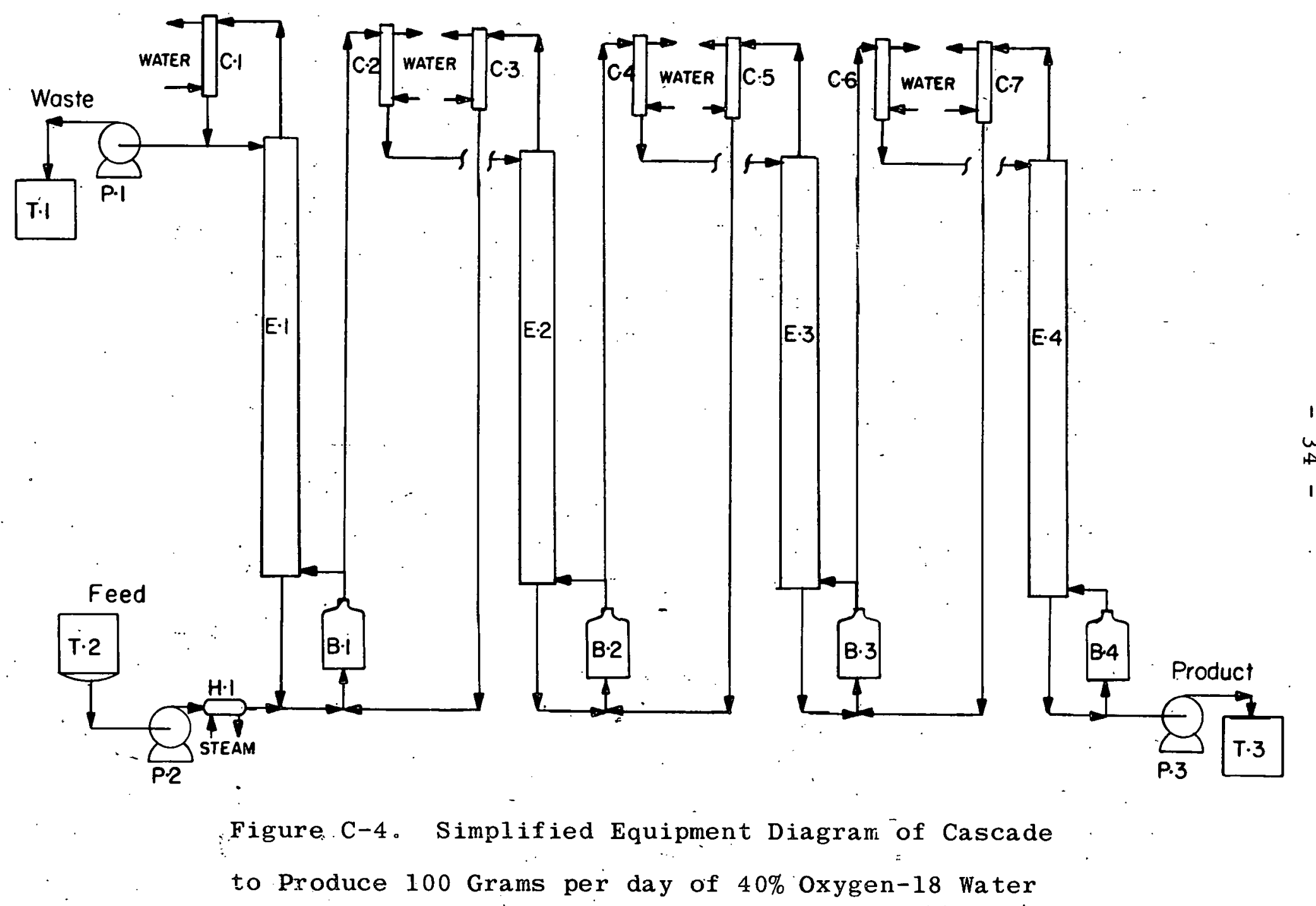


Table C-4. Cost of Installed Equipment

Cascade No. 5

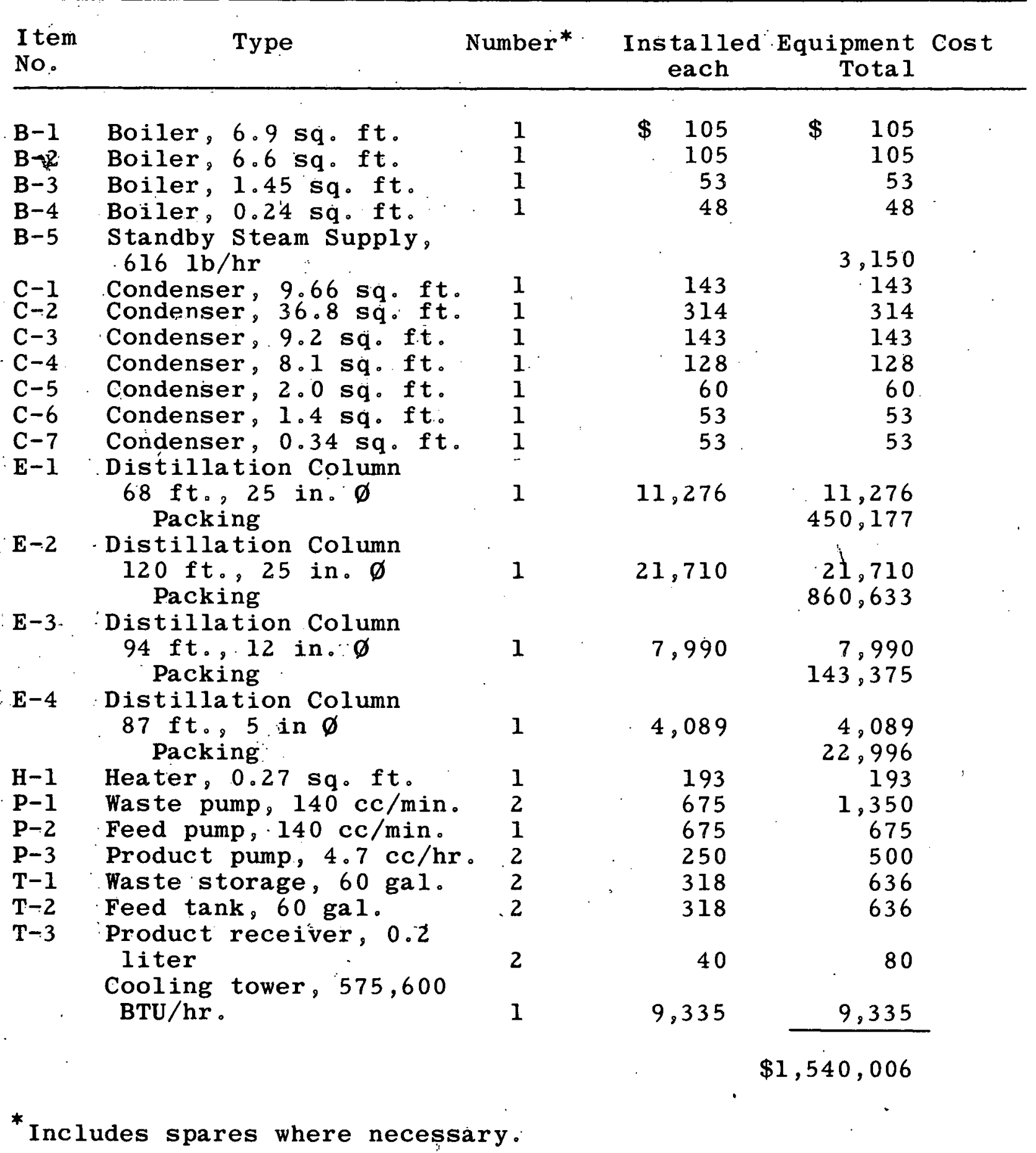




\section{Appendix "D" - Tabulated Costs}

Herein are presented the various charges which contribute to the total plant investment, annual fixed cost, annual variable cost, total annual operating cost, and cost per gram of product 
Table D-1. Total Plant Investment

Cascade 1

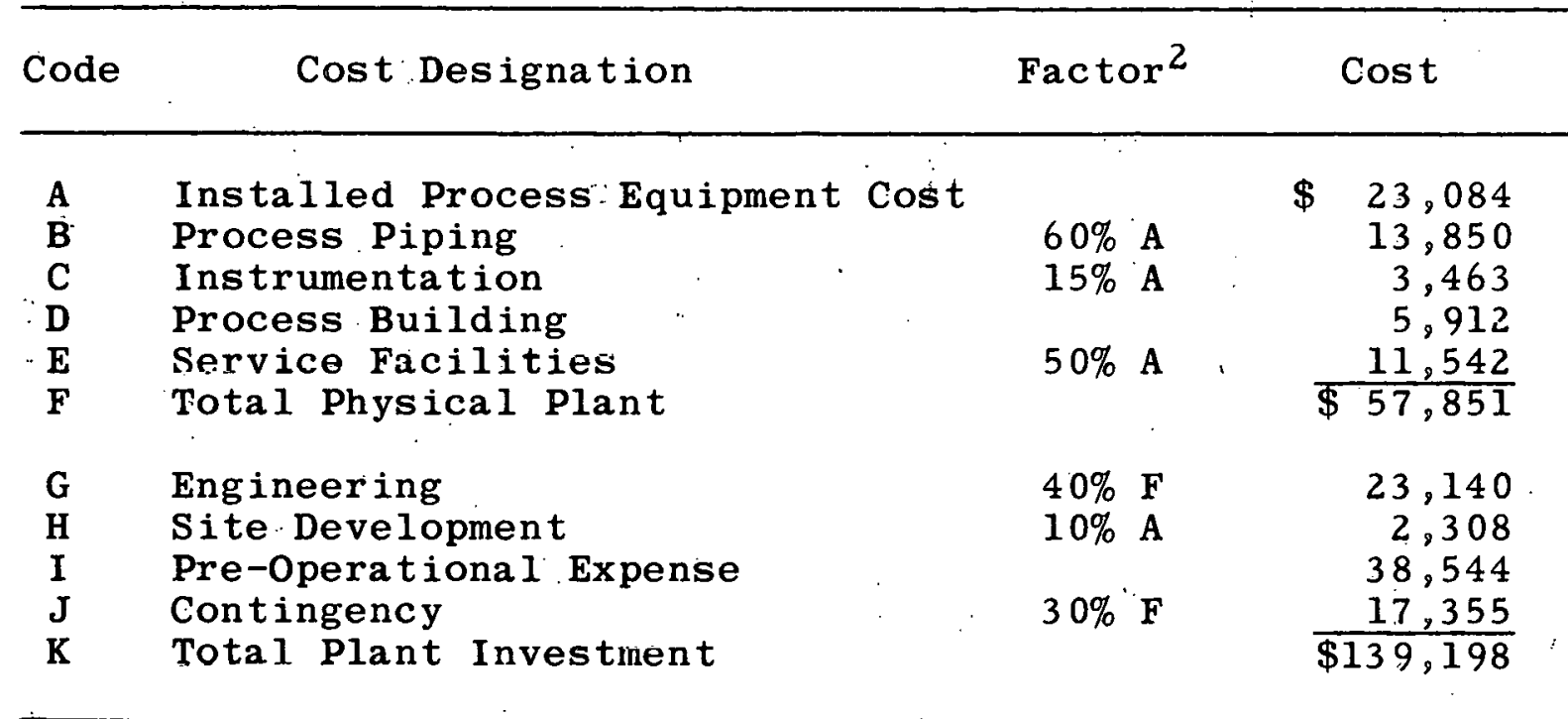

Table-D-2。 Annual Fixed Cost

Cascade 1

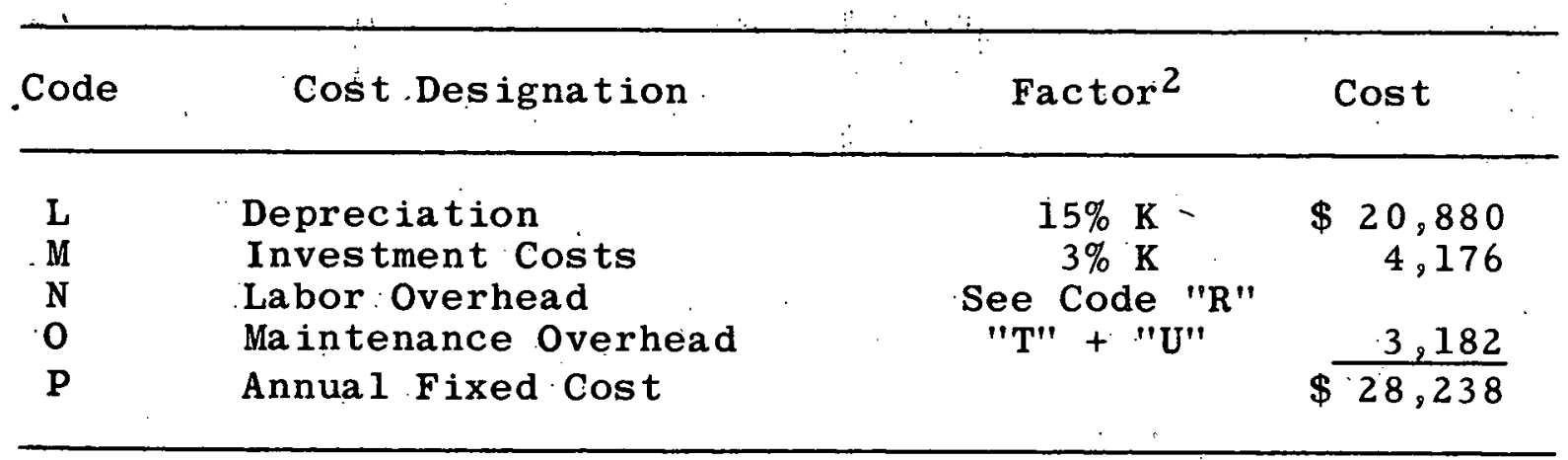


Table D-3...Annual Variable Cost

Cascade 1

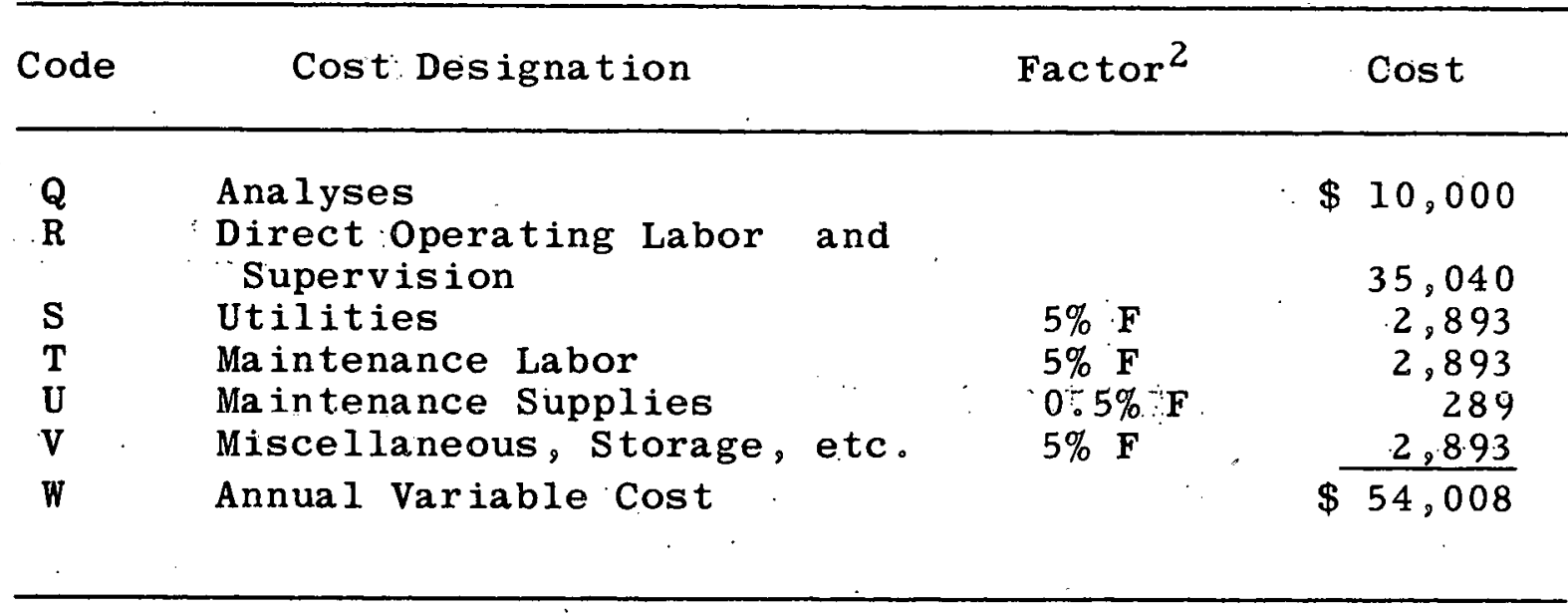

Table“D-4. Cost Summary

Cascade 1

Code Cost Designation Cost

AA Total Plant Investment

BB Annual Fixed Cost

$\$ 139,198$

CC : Annual Variable Cost

28,238

DD Total Annual Operating Cost

EE Cost per Gram of Oxygen-18.

54,008

Enriched Water

82,246

225 
Table D-5. Total Plant Investment

Cascade 2

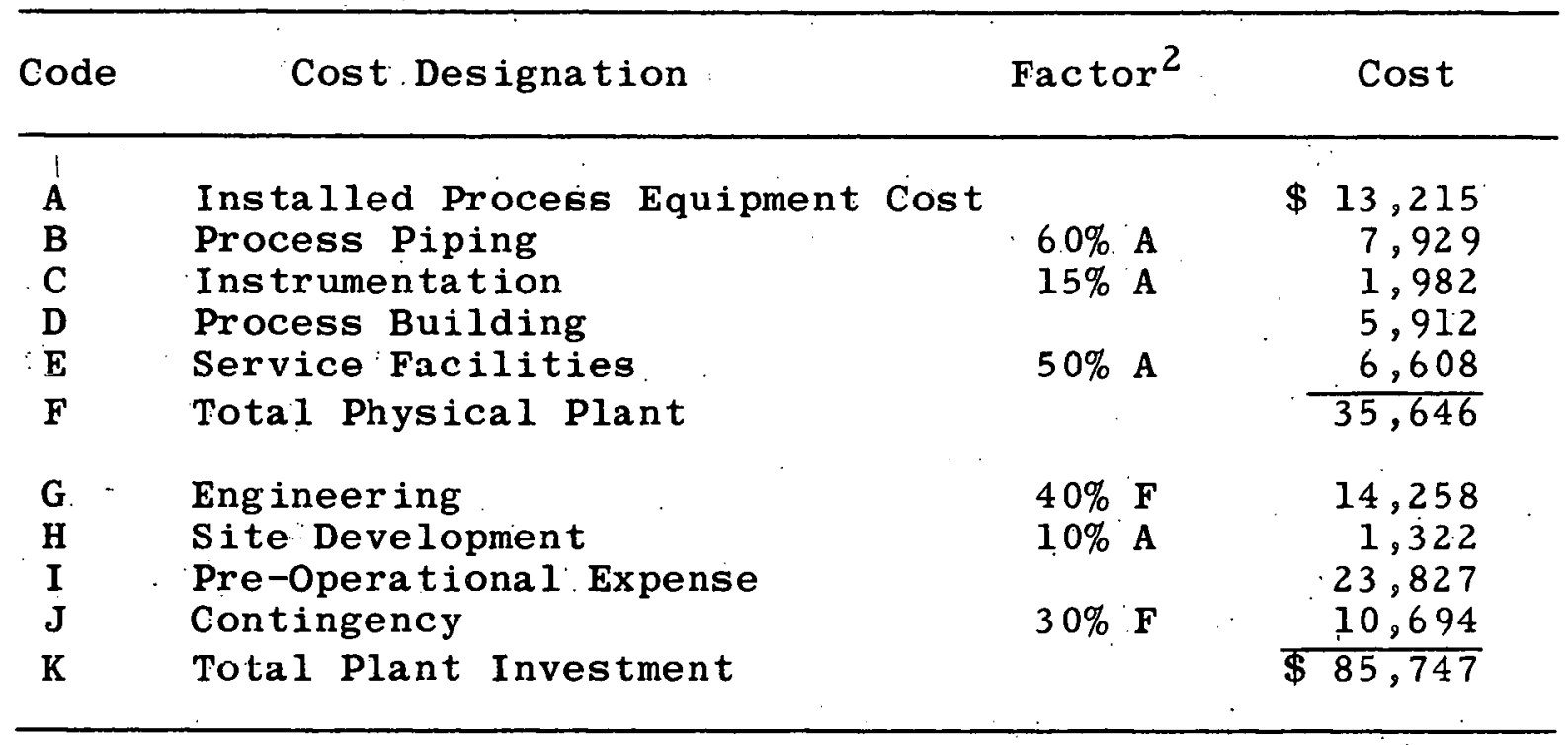

Table: D-6. Annual Fixed Cost

Cascade 2

\begin{tabular}{|c|c|c|c|c|}
\hline Code & Cost Designation & Factor ${ }^{2}$ & & Cost \\
\hline $\begin{array}{l}\mathrm{L} \\
\mathrm{M} \\
\mathrm{N} \\
\mathbf{O}\end{array}$ & $\begin{array}{l}\text { Depreciation } \\
\text { Investment Costs } \\
\text { Labor Overhead } \\
\text { Maintenance Overhead }\end{array}$ & $\begin{array}{rl}15 \% & \mathrm{~K} \\
3 \% & \mathrm{~K} \\
\text { See Code } & \mathrm{R} " \\
\text { "T" }+ \text { " } \mathrm{T} " \mathrm{U} "\end{array}$ & $\$$ & $\begin{array}{r}12,862 \\
2,572 \\
1,960\end{array}$ \\
\hline $\mathbf{p}$ & Annual Fixed Cost & & $\$$ & $\overline{17,394}$ \\
\hline
\end{tabular}


Table'D-7. Annual Variable Cost

Cascade $\cdot 2$

\begin{tabular}{lllr}
\hline Code & \multicolumn{1}{c}{ Cost Designation } & Factor & Cost \\
\hline $\mathbf{Q}$ & $\begin{array}{l}\text { Analyses } \\
\text { Direct Operating Labor and }\end{array}$ & & $\$ 10,000$ \\
$\mathbf{R}$ & $\begin{array}{l}\text { Supervision } \\
\text { Utilities }\end{array}$ & $5 \%: \mathbf{F}$ & 35,040 \\
$\mathbf{S}$ & Maintenance Labor & $5 \% \mathbf{F}$ & 1,782 \\
$\mathbf{T}$ & Maintenance Supplies & 1,782 \\
$\mathbf{U}$ & Miscellaneous, Storage, etc & $5 \%$ F & 1,782 \\
$\mathbf{V}$ & Annual Variable Cost & & $\$ 50,564$ \\
\hline
\end{tabular}

Table D-8, Cost Summary

Cascade 2 '

\begin{tabular}{clc}
\hline Code & \multicolumn{1}{c}{ Cost:Designation } & Cost \\
\hline AA & Total Plant Investment & $\$ 85,747$ \\
BB & Annual Fixed Cost & 17,394 \\
CC & Annual Variable Cost & 50,564 \\
DD & Total Annual Operating Cost & 67,958 \\
Cost per Gram of Oxygen-18 & 186 \\
\hline
\end{tabular}


Table: D-9. Total Plant Investment

Cascade 3

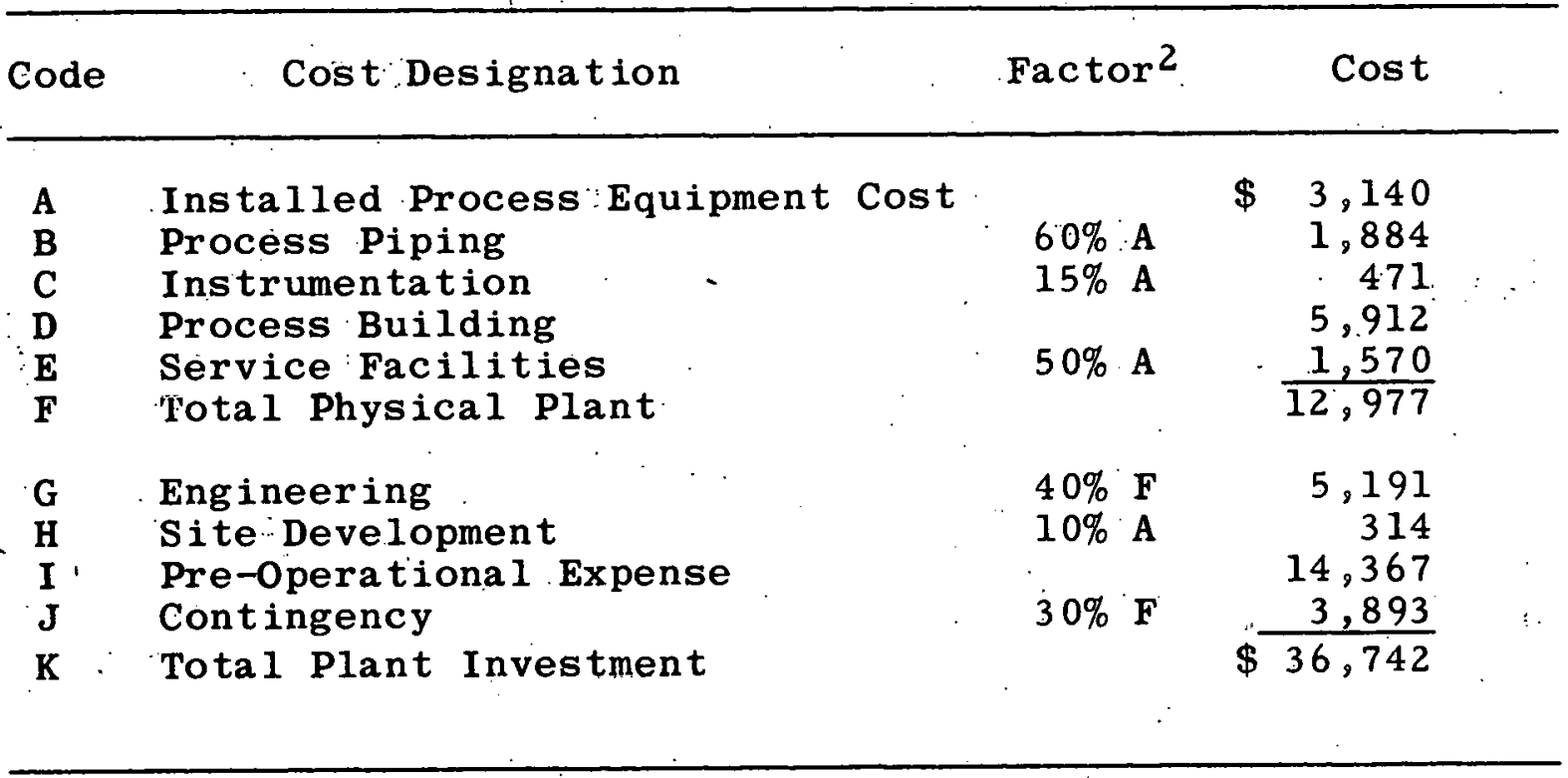

Table D-10. Annual Fixed Cost

Cascade 3

\begin{tabular}{llll}
\hline Code & Cost Designation & Factor & Cost \\
\hline $\mathbf{L}$ & Depreciation & $15 \% \mathrm{~K}$ & $\$ 5,511$ \\
$\mathrm{M}$ & Investment Costs & $3 \% \mathrm{~K}$ & 1,102 \\
$\mathbf{N}$ & Labor Overhead & See Code "R" & \\
$\mathbf{O}$ & Maintenance Overhead & "T" + "U" & $\frac{714}{7,327}$ \\
$\mathbf{P}$ & Annual Fixed Cost & & $\$ 7$ \\
\hline
\end{tabular}


Table: D-11。Annual Variable Cost

Cascade 3

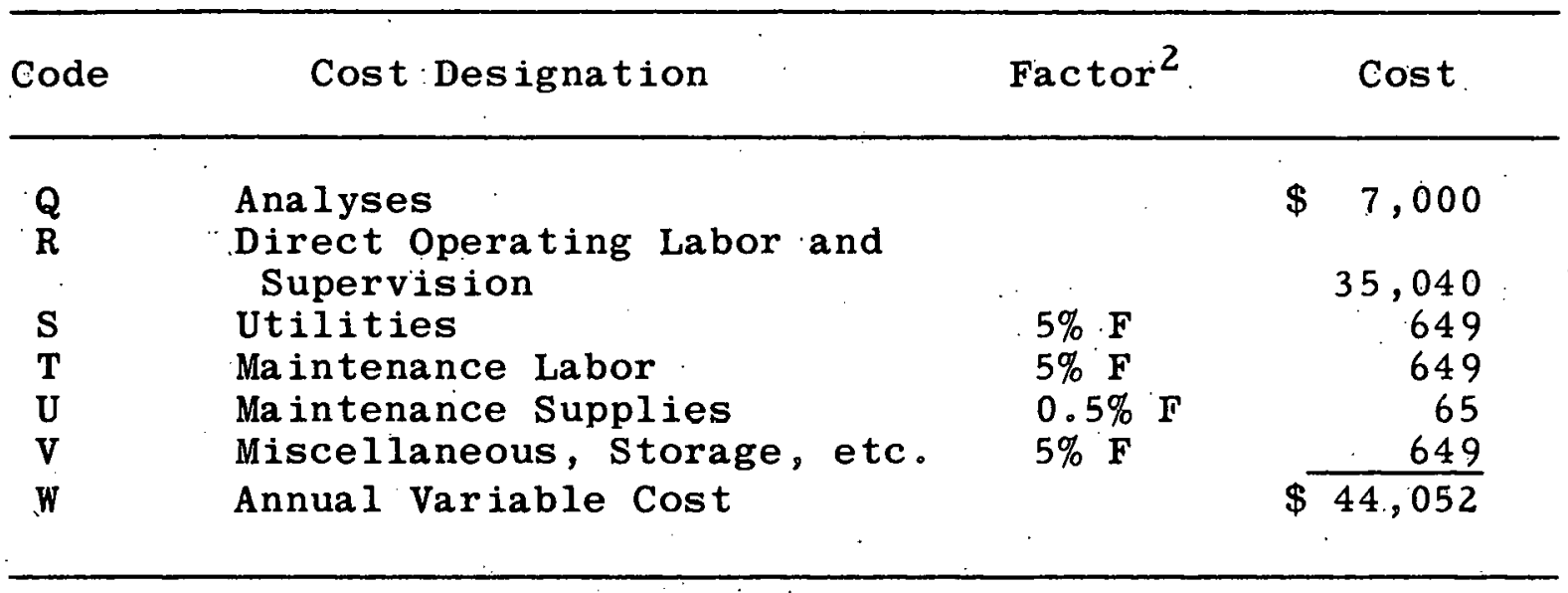

Table D-12。 Cost Summary

Cascade 3

Code

Cost Designation

Cost

AA

Total Plant Invèstment

BB

Annual Fixed Cost

$\$ 36,742$

CC

Annual Variable Cost

7,327

DD

Total Annual Operating Cost

44,052

EE

Cost per Gram of Oxygen-18

51,379

Enriched Water 
Table: $\mathrm{D}-13$. Cost Summary

Cascade 4

\begin{tabular}{llr}
\hline Code & \multicolumn{1}{c}{ Costidesignation } & \multicolumn{1}{c}{ Cost } \\
\hline AA & $\begin{array}{l}\text { Total Plant Investment } \\
\text { BB }\end{array}$ & $\$ 9,800,000$ \\
CC & $\begin{array}{l}\text { Annual Fixed Cost } \\
\text { Annual Variable Cost } \\
\text { Total Annual Operating Cost } \\
\text { EE }\end{array}$ & $\begin{array}{r}1,676,000 \\
660,000 \\
\text { Cost per Gram of Oxygen-18 } \\
\text { Enriched Water }\end{array}$ \\
\hline
\end{tabular}

Table $\mathrm{D}-14 \ldots$ Total Plant Investment

Cascade 5

\begin{tabular}{|c|c|c|c|c|c|}
\hline Code & Cost Designation & & Factor ${ }^{2}$ & & Cost \\
\hline $\begin{array}{l}\text { A } \\
\text { B } \\
\text { C } \\
\text { D } \\
\text { E }\end{array}$ & $\begin{array}{l}\text { Installed Process Equipment } \\
\text { Process Piping } \\
\text { Instrumentation } \\
\text { Process Building } \\
\text { Service Facilities }\end{array}$ & Cost & $\begin{array}{ll}60 \% & \mathrm{~A} \\
15 \% & \mathrm{~A} \\
50 \% & \mathrm{~A}\end{array}$ & $\$$ & $\begin{array}{r}1,540,006 \\
924,004 \\
231,001 \\
8,868 \\
770,003 \\
2172,007\end{array}$ \\
\hline $\begin{array}{l}\mathbf{G} \\
\mathbf{H} \\
\mathbf{I} \\
\mathbf{J}\end{array}$ & $\begin{array}{l}\text { Engineering } \\
\text { Site-Development } \\
\text { Pre-Operational Expense } \\
\text { Contingency }\end{array}$ & . & $\begin{array}{ll}40 \% & \mathrm{~F} \\
10 \% & \mathrm{~A} \\
30 \% & \mathrm{~F}\end{array}$ & · & $\begin{array}{r}1,389,553 \\
154,001 \\
67,452 \\
1,042,165 \\
\end{array}$ \\
\hline $\mathbf{K}$ & Total Plant Investment & & & $\$$ & $6,127,053$ \\
\hline
\end{tabular}


Table $D=15$. Annual Fixed Cost

Cascade 5

\begin{tabular}{|c|c|c|c|}
\hline Code & Cost : Designation & Factor ${ }^{2}$ & Cost \\
\hline $\begin{array}{l}\mathrm{L} \\
\mathrm{M} \\
\mathrm{N} \\
\mathrm{O}\end{array}$ & $\begin{array}{l}\text { Depreciation } \\
\text { Investment Costs } \\
\text { Labor Overhead } \\
\text { Maintenance Overhead }\end{array}$ & $\begin{array}{c}15 \% \mathrm{~K} \\
3 \% \mathrm{~K} \\
\text { See Code "R" } \\
\text { "T"T + "U" }\end{array}$ & $\begin{array}{r}\$ 919,058 \\
183,812 \\
191,063 \\
\end{array}$ \\
\hline $\mathbf{P}$ & Annual Fixed Cost & & $\$ 1,293,933$ \\
\hline
\end{tabular}

Table D-16. Annual Variable Cost

Cascade 5

\begin{tabular}{|c|c|c|c|}
\hline Code & Cost Designation & Factor ${ }^{2}$ & Cost \\
\hline $\begin{array}{l}\mathbf{Q} \\
\mathbf{R}\end{array}$ & $\begin{array}{l}\text { Analyses } \\
\text { Direct Operating Labor and } \\
\text { Supervision }\end{array}$ & . & $\begin{array}{r}\$ 15,000 \\
61,320\end{array}$ \\
\hline $\begin{array}{l}\mathrm{S} \\
\mathrm{T} \\
\mathrm{U} \\
\mathrm{V}\end{array}$ & $\begin{array}{l}\text { Utilities } \\
\text { Maintenance Labor } \\
\text { Maintenance Supplies } \\
\text { Miscellaneous, Storage, etc. }\end{array}$ & $\begin{array}{l}5 \% \\
5 \% \\
0.5 \% \\
0 \% \cdot \mathbf{F}\end{array}$ & $\begin{array}{r}173,694 \\
173,694 \\
17,369 \\
173,694 \\
\end{array}$ \\
\hline$W$ & Annual Variable Cost & & $\$ 614,771$ \\
\hline
\end{tabular}


Table D-17. Cost Summary

Cascade 5

\begin{tabular}{llr}
\hline Code & Cost.Designation & Cost \\
\hline AA & $\begin{array}{l}\text { Total Plant Investment } \\
\text { BB }\end{array}$ & $\$, 6,127,053$ \\
CC & $\begin{array}{l}\text { Annual Fixed Cost } \\
\text { Annul Variable Cost } \\
\text { Total Annual Operating Cost } \\
\text { EE }\end{array}$ & $\begin{array}{l}\text { Cost per Gram of Oxygen-18 } \\
\text { Enriched Water }\end{array}$ \\
\hline
\end{tabular}

Table: D-18。 Cost Summary

Cascade 6

Code

Cost Designation

$\cos t$

$\begin{array}{llr}\text { AA } & \text { Total Plant Investment } & \$ 1,750,000 \\ \text { BB } & \text { Annual Fixed Cost } & 350,000 \\ \text { CC } & \text { Annual Variable Cost } & 600,000 \\ \text { DD } & \text { Total Annual Operating Cost } & 950,000 \\ \text { EE } & \text { Cost per Gram of Oxygen-18 } & \\ & \text { Enriched Water } & 26\end{array}$




\section{Appendix "E" - Variation of Cascade Costs}

\section{with Product Purity and Production Rate}

In this section are presented graphs depicting the variation of the various cascade costs with product purity and production rate. In each case, the cost associated with the 100 gram per day, $40 \%$ oxygen-18 cascade has been extrapolated by the method of parallel curves to furnish order of magnitude estimates of cost for the large scale production of $3 \%$ and $99 \%$ oxygen-18 enriched water. This approximate method yields self consistent data for the 100 gram per day, $99 \%$ oxygen-18 case.: It is not quite so exact for the 100 gram per day, $3 \%$ oxygen18 case. 


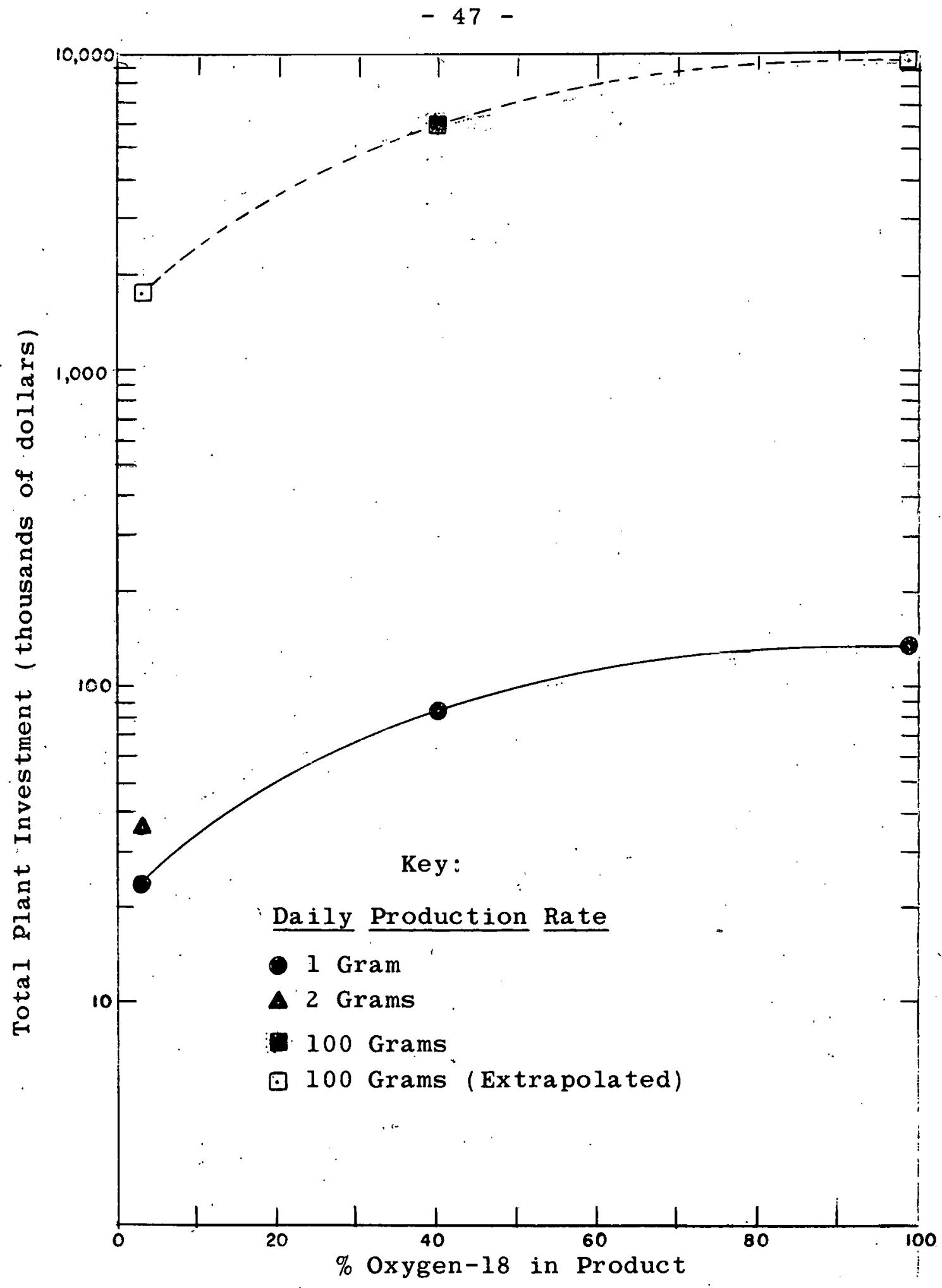

Figure E-1. Variation of Total Plant Investment with Product'Purity and Production Rate 


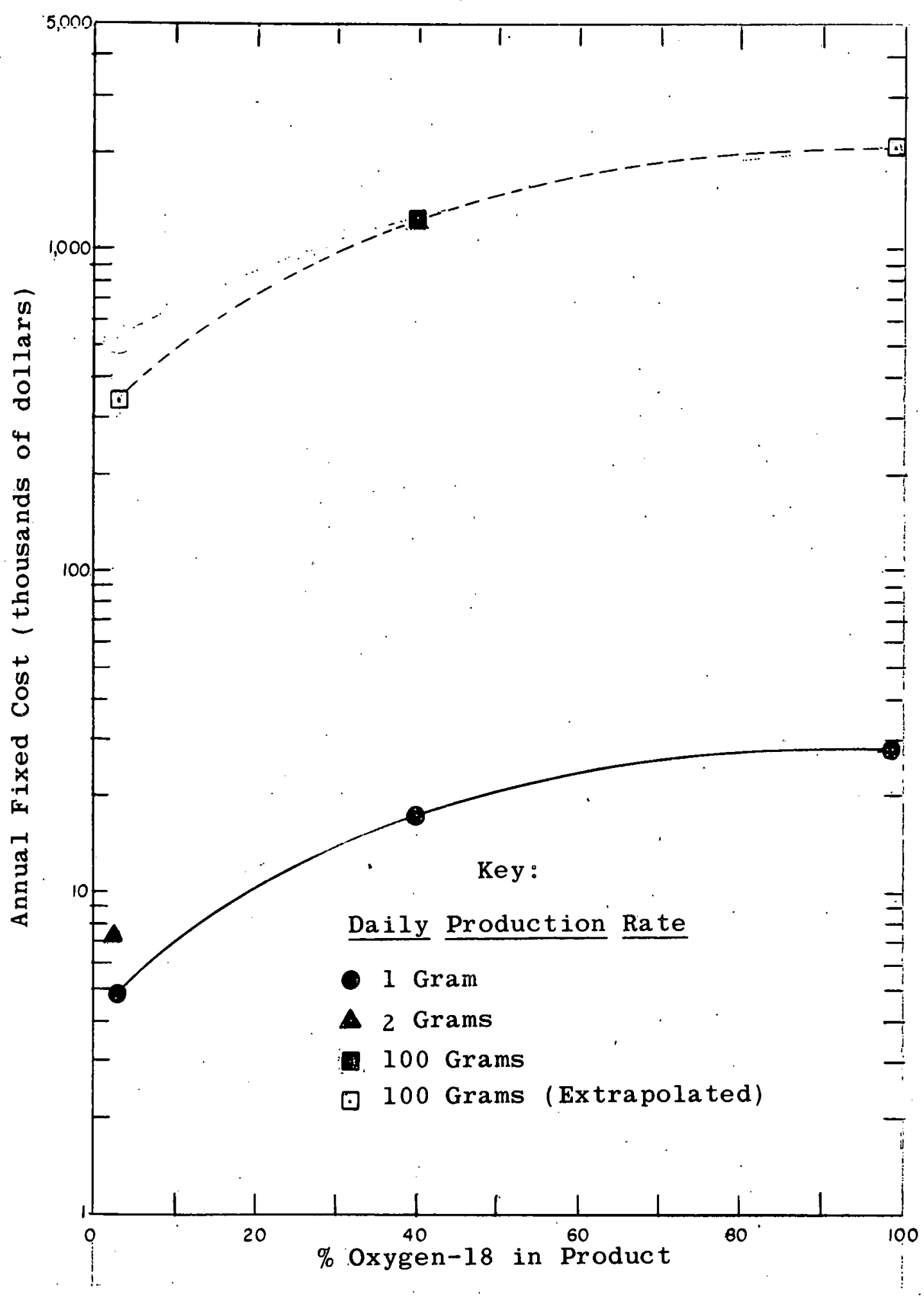

Figure E-2. Variation of Annual Fixed Cost with Product Purity and Production Rate 


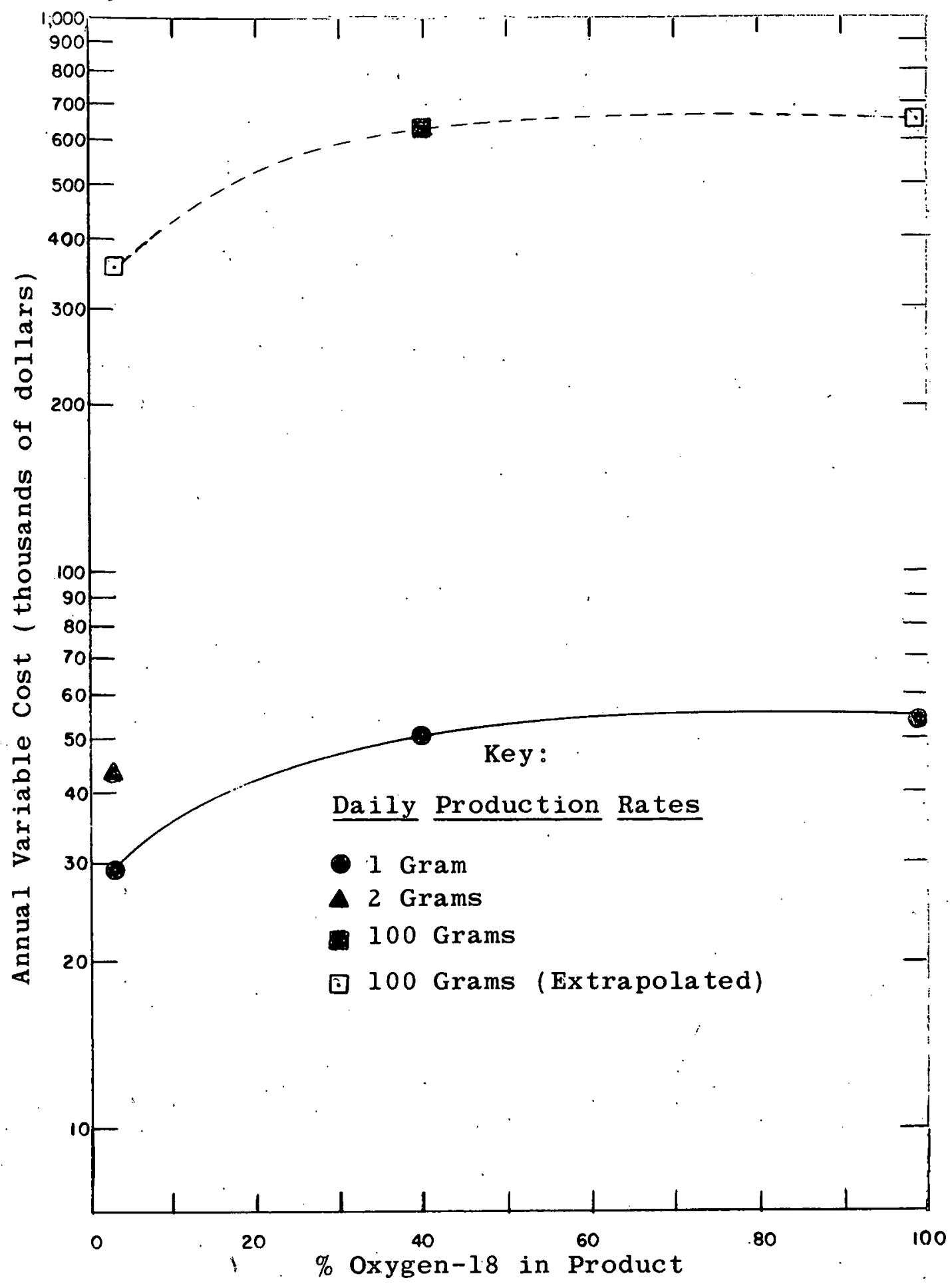

Figure E-3. Variation of Annual Variable Cost with Product Purity and Production Rate 


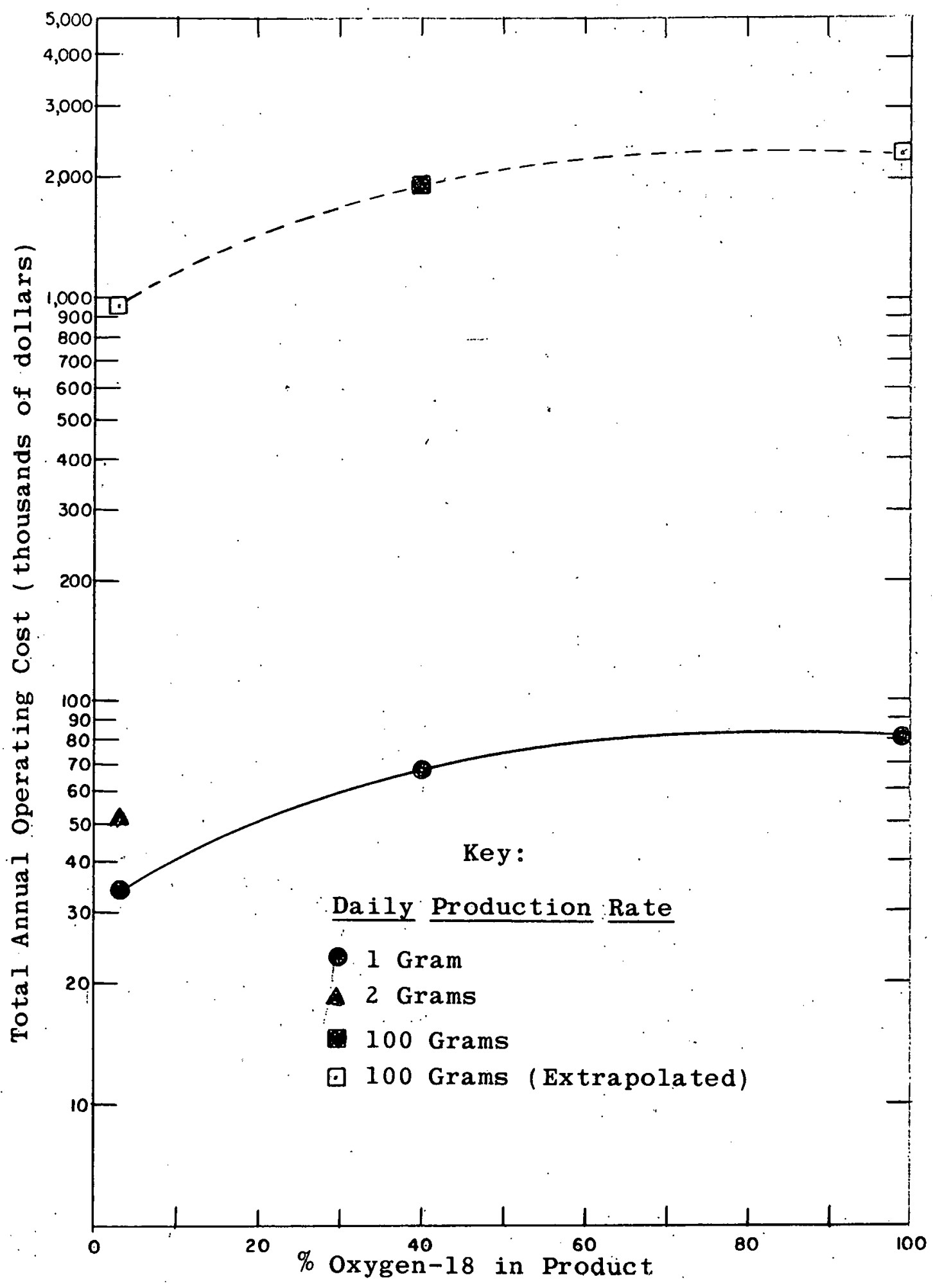

Figure E-4. Variation of Annual Operating, Cost with Product Purity and Production Rate 


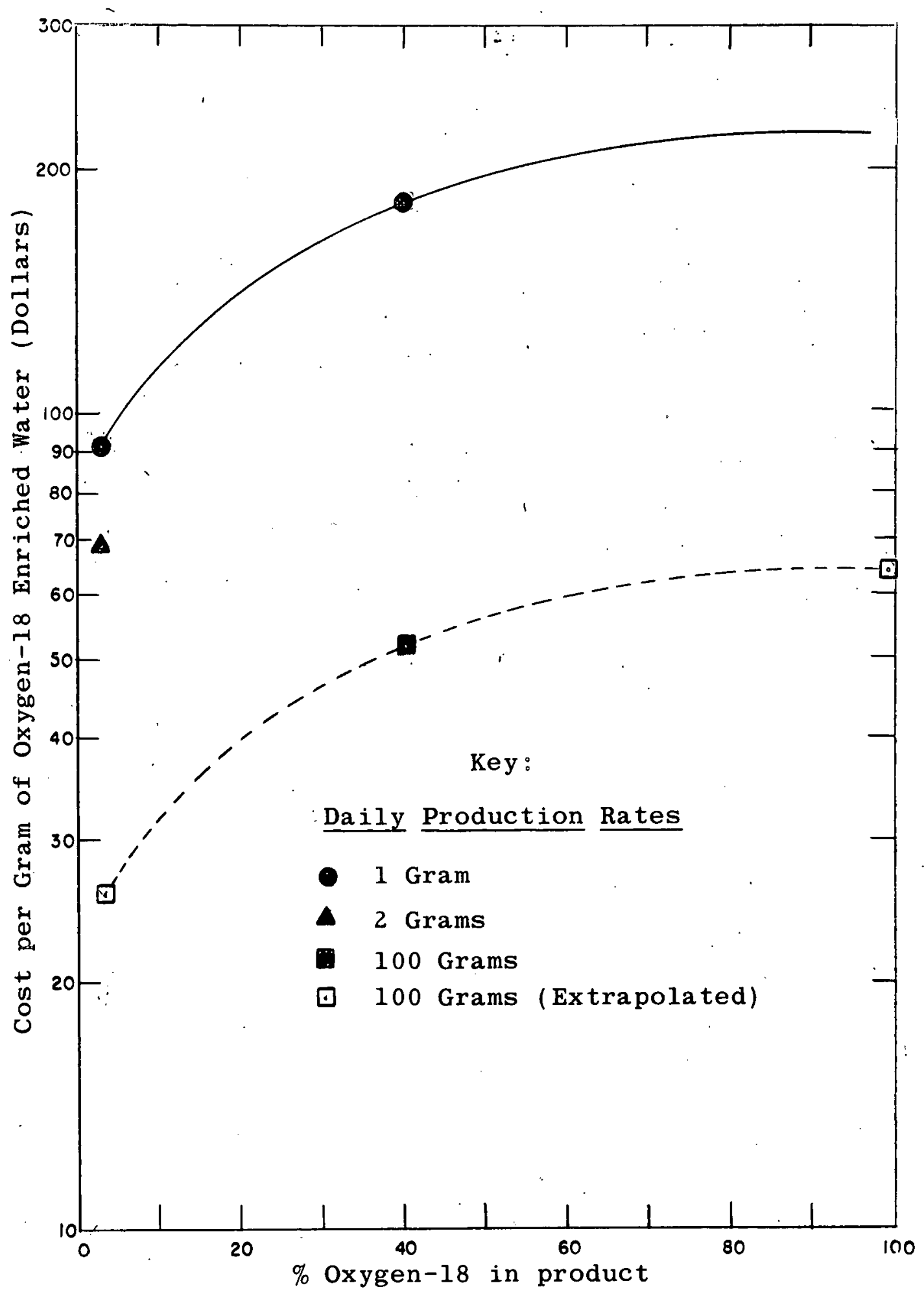

Figure E-5. Variation of Product Cost with Product Purity and Production Rate 


\section{References}

1. I. Dostróvsky and $A$ " Raviv; "Separation of the Heavy Isotopes of Oxygen by.'Distillation," page 336 , Proceedings of the Symposium on Isotope Separation, Amsterdam, 1957, North Holland Publishing Company, Ams terdam, 1958 .

2. C. H. Chilton, "Cost Data Correlated," Chem. Engr.? June 1949.

3. I..Dostrovsky, personal communication.

4.. R.. Williams, "Six Tenths Factor Aids in Approximating Costs," Chem。Engr. 54, 124-5 (Dec。1947)。 


\section{DISTR IBUTION}

$$
\begin{aligned}
& \text { 1. G. E. Boyd } \\
& \text { 2-5. J. S . Drury } \\
& \text { 6. B. B. Klima } \\
& \text { 7. J.A. Swartout } \\
& \text { 8. E.H. Taylor } \\
& \text { 9. A. M. We inberg } \\
& \text { 10. ORNL-RC } \\
& \text { 11-16. H. M. Roth, ORO, AEC } \\
& \text { 17-18. Central Research Library - } \\
& \text { I9. Döcument Reference Section } \\
& \text { 20. M. J": Skinner" } \\
& \text { 21-22. Laboratory Records }
\end{aligned}
$$

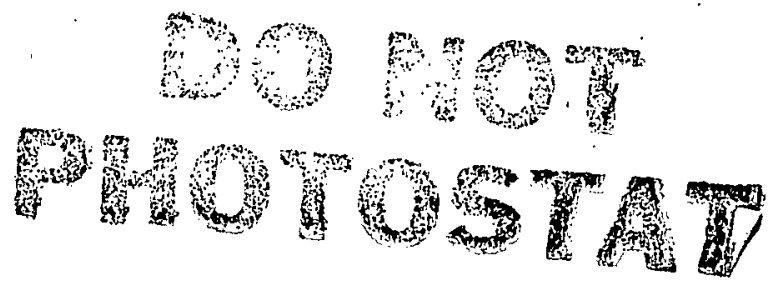

